\title{
Microzooplankton grazing in the Eastern Bering Sea in summer
}

\author{
Diane K. Stoecker ${ }^{\mathrm{a}, *}$, Alison Weigel ${ }^{\mathrm{a}}$, Joaquim I. Goes ${ }^{\mathrm{b}}$ \\ a University of Maryland Center for Environmental Science, Horn Point Laboratory, P.O. Box 775, Cambridge, MD 21613, USA \\ b 10 Marine Biology, Department of Marine Biology and Paleoenvironment, Lamont Doherty Earth Observatory at Columbia University, \\ 61 Route 92, Palisades, NY 10964, USA
}

\section{A R T I C L E I N F O}

Keywords:

Bering Sea

Microzooplankton grazing

Dilution method

Deep chlorophyll maximum

$\mathrm{Fv} / \mathrm{Fm}$

\begin{abstract}
A B S T R A C T
Dilution experiments to estimate microzooplankton grazing on phytoplankton were conducted during the summers of 2008, 2009, and 2010 in the Eastern Bering Sea as part of the BEST-BSIERP integrated ecosystem project. All three summers followed cold springs in the Bering Sea. Average microzooplankton grazing coefficients were relatively similar among regions, ranging from 0.16 to $0.34 \mathrm{~d}^{-1}$ in simulated in situ incubations with mixed-layer water collected from the depth of the $55 \% I_{\mathrm{o}}$ isolume. In Off Shelf and Outer Shelf domains, microzooplankton consumed $67-78 \%$ of phytoplankton daily growth but in the Middle and Inner Shelf domains, microzooplankton grazing exceeded phytoplankton daily growth. Regional estimates of microzooplankton ingestion of phytoplankton carbon ranged from 4.4 to $11.0 \mu \mathrm{g} \mathrm{C} \mathrm{d}^{-1}$, with highest ingestion in the Off Shelf, Outer Shelf, and Alaska Peninsula regions and, lower ingestion in the Middle Shelf and Inner Shelf regions. On the northern Middle Shelf, a deep chlorophyll maximum (DCM) occurred at most stations. Grazing coefficients in the DCM were similar in magnitude to coefficients in the corresponding mixed layer. However, because of the higher phytoplankton biomass in the DCM, estimated microzooplankton ingestion and secondary production per liter were higher in the DCM than in the mixed layer. Measurements of photosynthetic quantum yields (Fv/ $\mathrm{Fm}$ ) in whole seawater and diluted treatments indicated that with some plankton assemblages, dilution had a negative effect on phytoplankton physiology and could have compromised their growth rates. This could have also resulted in an underestimation of microzooplankton grazing. Nevertheless, it is clear that microzooplankton grazing consumed most of the phytoplankton production in summer, and that microzooplankton were an important link in food webs supporting larger zooplankton and in carbon flow in the Eastern Bering Sea.
\end{abstract}

(c) 2013 Elsevier Ltd. All rights reserved.

\section{Introduction}

The $<200 \mu \mathrm{m}$ fraction of zooplankton assemblages, which includes both microzooplankton and nanozooplankton, is an important link between primary producers and higher trophic levels in sub-polar and polar waters as well as in temperate and tropical waters (Levinsen and Nielsen, 2002; Calbet and Saiz, 2005; Campbell et al., 2009; Sherr et al., 2013). They are important grazers on pico, nano and microplankton, including large diatoms (Sherr et al., 2009, 2013). Previous studies have shown that the $<200 \mu \mathrm{m}$ fraction is the major consumer of primary production in summer in the Eastern Bering Sea (Liu et al., 2002; Olson and Strom, 2002; Strom and Fredrickson, 2008). In Arctic and subArctic as well as temperate and tropical seas, microzooplankton are important prey for mesozooplankton, including both small and large crustacean zooplankton (Levinsen and Nielsen, 2002; Campbell et al., 2009) and hence are a significant component of the food web and carbon cycle.

\footnotetext{
* Corresponding author. Tel.: +1 410 2218407; fax: +1 4102218490 .

E-mail addresses: stoecker@umces.edu (D.K. Stoecker), jig@ideo.columbia.edu (J.I. Goes).
}

Although microzooplankton can graze on large as well as small phytoplankton, including chain forming dinoflagellates (Strom et al., 2007; Sherr et al., 2013), their grazing rates, particularly microzooplankton biomass specific rates, can be influenced by phytoplankton species composition, physiological state and cell size (Olson and Strom, 2002; Strom and Fredrickson, 2008). In the Eastern Bering Sea, phytoplankton $<5 \mu \mathrm{m}$ comprise $\sim 70 \%$ of the chlorophyll $a$ in summer and autotrophic biomass is dominated by phytoflagellates (Lomas et al., 2012; Moran et al., 2012). Sporadic blooms of chain forming diatoms (mostly Chaetoceros and Thalassiosira spp.) and blooms of the solitary or colonial phytoflagellate Phaeocystis pouchetti occur in response to tidal and storm mixing or intrusion of deeper water onto the shelf (Sukhanova et al., 1999; Sambrotto et al., 2008). In late spring and summer, prolonged blooms of diatoms and $P$. pouchetti are associated with the shelf break and shelf partition fronts (Flint et al., 2002). During the anomalously warm and stratified spring of 1997, a bloom of the coccolithophorid, Emiliana huxleyi, developed on the southeastern shelf and during summers 1998-2000 the bloom was present (Stockwell et al., 2001; Merico et al., 2004). In summer, particularly on the northern shelf, a deep chlorophyll maximum (DCM) composed primarily of diatoms has often been encountered. It is 
not clear if the DCM is a resident low light population or physiologically inactive settled material (Moran et al., 2012; Stabeno et al., 2012a), and to what extent it is grazed by the $<200 \mu \mathrm{m}$ zooplankton.

Microzooplankton were sampled as part of the Bering Sea Project ecosystem study in the Eastern Bering Sea in summers of 2008, 2009, and 2010 (Stoecker et al., this issue), all part of a four year "cold" period characterized by extensive sea ice in spring (Stabeno et al., 2012b). Average summer microzooplankton (defined as $\sim 20$ $200 \mu \mathrm{m}$ size range) densities ranged from $4 \times 10^{3}$ to $25 \times 10^{3}{\text { cells } \mathrm{l}^{-1}}^{-1}$ in the mixed layer in stratified shelf waters but were about half that concentration in less stratified waters near the shelf break. High ratios ( $>1$ ) of microzooplankton biomass to phytoplankton biomass were observed when chlorophyll concentrations were below $1 \mu \mathrm{g} \mathrm{l}^{-1}$ in the mixed layer (Stoecker et al., this issue). In coastal (inner domain) and Middle Shelf (middle domain) waters, the average biomass of microzooplankton in the mixed layer was often equal to or higher than that of phytoplankton. Microzooplankton were also found in the deep chlorophyll maxima (DCM) on the shelf; densities of microzooplankton in these high chlorophyll layers were usually similar to in the lower chlorophyll mixed layer. Microzooplankton abundance and biomass data from summers 2008-2010, along with results from previous studies during both "warm" and "cold" years in the Eastern Bering Sea (Liu et al., 2002; Olson and Strom, 2002; Strom and Fredrickson, 2008), indicate that summer microzooplankton population differences among domains are far greater than differences due to year-to-year variations in sea ice extent and water temperature (Stoecker et al., this issue).

Dilution grazing experiments were conducted with the $<200 \mu \mathrm{m}$ fraction of plankton in conjunction with microzooplankton sampling on the BEST-BSIERP summer cruises in 2008, 2009, and 2010. Although standard dilution experiments include grazing by both microzooplankton and nanozooplankton, they are commonly called "microzooplankton" dilution grazing experiments. Herein, this convention was followed. Prior to our study, summer data on grazing by microzooplankton in the Eastern Bering Sea were limited to the southern shelf and the productive waters around the Pribilof Islands (Olson and Strom, 2002; Hunt et al., 2008; Strom and Fredrickson, 2008). The primary goal was to conduct dilution grazing experiments across a spectrum of environments and to compare microzooplankton grazing among domains. One objective was to determine if grazing and its impact on phytoplankton correlated with the biomass of microzooplankton (Stoecker et al., this issue) and/or the dominance of certain phytoplankton taxa. Low grazing by the $<200 \mu \mathrm{m}$ fraction can occur during blooms of coccolithophorids (Olson and Strom, 2002) and P. pouchetti (reviewed in Nejstgaard et al. (2007)). Another objective was to determine if grazing by the $<200 \mu \mathrm{m}$ fraction was important in the DCM since this is a characteristic feature of the northern shelf in summer (Stabeno et al., 2012a).

\section{Materials and methods}

\subsection{Sampling}

Microzooplankton grazing experiments were conducted on Bering Sea Project summer cruises in 2008, 2009 and 2010 on the USCG Healy (HLY-08-03, July 3-July 31), R/V Knorr (KNORR 195-10, June 14 to July 13) and R/V T.G. Thompson 2010 (TN-250, June 16-July 14). The stations at which dilution grazing experiments were conducted are shown in

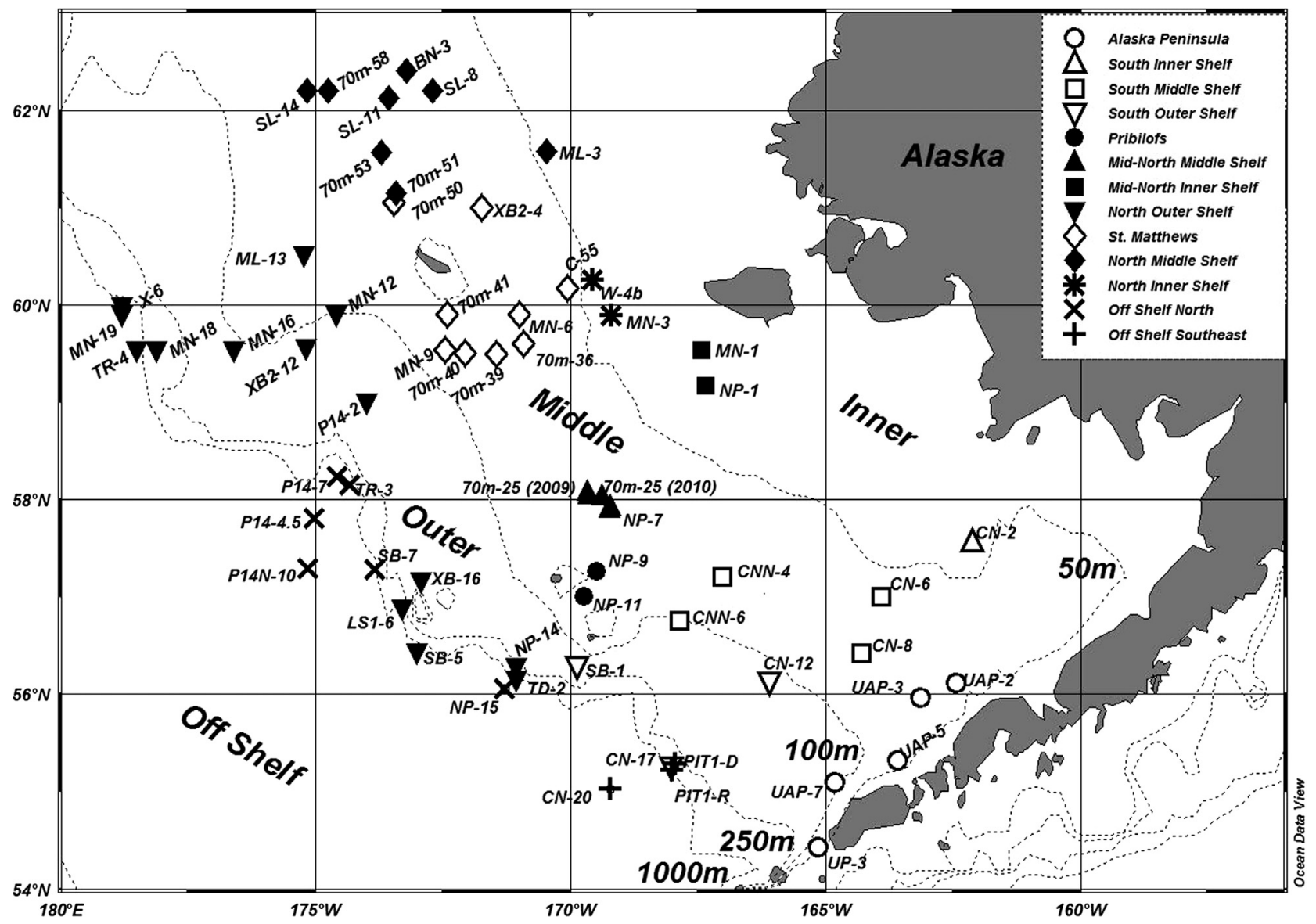

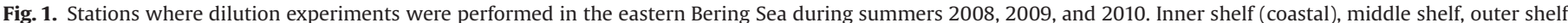
and off shelf areas are indicated. Refer to Table 1 for list of stations, regions and experimental parameters; experiments were not performed at all stations in all years. 
Fig. 1; the stations and depths of experiments for each year are given in Table 1. Stations are grouped by marine regions in the Bering Sea Project area as delineated by Ortiz et al. (2012). In most cases, dilution grazing experiments were undertaken in conjunction with the phytoplankton biomass and primary productivity casts with water collected from the depth of the 55\% of surface PAR irradiance level (Lomas et al., 2012). At all stations the 55\% irradiance level was in the surface mixed layer, with the sampling depth for mixed layer incubations ranging from 3 to $10 \mathrm{~m}$ (Table 1). In 2010 we also undertook microzooplankton grazing experiments using assemblages from the DCM which was located based on chlorophyll fluorescence profiles from the core CTD casts. Supporting information including water temperature, salinity, chlorophyll $a$, inorganic nutrients and irradiance were obtained from core program measurements or from the productivity casts (Lomas et al., 2012). Data are archived at http://beringsea.eol.ucar.edu.

\subsection{Dilution experiments}

Dilution grazing experiments are the only method available for estimating community grazing by the $<200 \mu \mathrm{m}$ fraction on the whole phytoplankton community. This method estimates phytoplankton growth rates $(\mu)$ and mortality of phytoplankton due to combined microzooplankton and nanoplankton grazing $(g)$ (Landry, 1993). Dilution grazing experiments include all grazers $\leq 200 \mu \mathrm{m}$ in size, including small heterotrophic and mixotrophic flagellates, as well as the larger ciliates and heterotrophic and mixotrophic dinoflagellates, but are commonly referred to as "microzooplankton" grazing experiments.

Pre-screened $(<200 \mu \mathrm{m})$ whole seawater (WSW), containing natural assemblages of phytoplankton and microzooplankton, was diluted with filtered, particle free seawater (FSW) from the same sample. Dilution reduces microzooplankton encounter rates with phytoplankton prey; in highly dilute treatments net growth rate (NGR) of phytoplankton approach the intrinsic growth rate $(\mu)$. Phytoplankton mortality due to microzooplankton grazing was calculated as $\mu$-NGR. A modified dilution method, the two-point method (Landry et al., 2008) was used because it is more efficient than the original method. The original and the two-point method were compared in grazing experiments conducted in the coastal Gulf of Alaska (Strom et al., 2006) and in the SE Bering Sea (Strom and Fredrickson, 2008) and were found to provide similar results.

In nutrient limited waters, which can occur in summer on the Bering Sea Shelf (Strom and Fredrickson, 2008), nutrient regeneration due to micrograzers can be important in supplying inorganic nutrients for phytoplankton growth. This would violate the first assumption of the dilution technique, that phytoplankton growth rate is not influenced by dilution (Landry, 1993). To circumvent this problem, inorganic nutrients can be added to all the bottles. However, then the estimated phytoplankton growth rates are no longer similar to in situ rates. In this situation, it is

Table 1

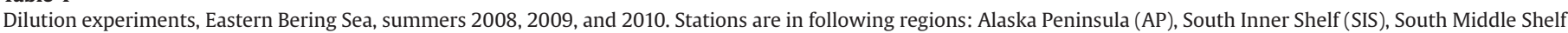

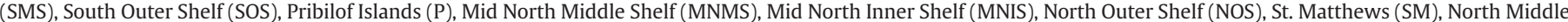

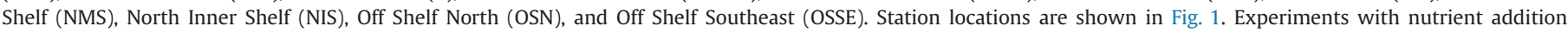

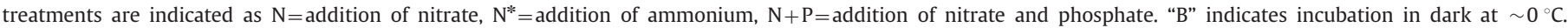
"CF" indicates experiment with a carbon filtration treatment. " $\mathrm{F}$ " indicates variable fluorescence measurements.

\begin{tabular}{|c|c|c|c|c|c|c|c|c|c|c|c|}
\hline Region & Date & Station & $\begin{array}{l}\text { Sample } \\
\text { depth (m) }\end{array}$ & $\begin{array}{l}\text { Water } \\
\text { temp. }\left({ }^{\circ} \mathrm{C}\right)\end{array}$ & & Region & Date & Station & $\begin{array}{l}\text { Sample } \\
\text { depth (m) }\end{array}$ & $\begin{array}{l}\text { Water } \\
\text { temp. }\left({ }^{\circ} \mathrm{C}\right)\end{array}$ & \\
\hline AP & $07 / 04 / 08$ & UP-3 & 5 & 5.39 & $\mathrm{~N}$ & NOS & $07 / 05 / 10$ & ML-13 & 35 & -1.07 & B \\
\hline AP & 06/15/09 & UAP-7 & 3 & 6.08 & & NOS & $06 / 27 / 10$ & SB-5 & 4 & 5.44 & $\mathrm{~N}+\mathrm{P}$ \\
\hline AP & $06 / 16 / 09$ & UAP-3 & 3 & 6.49 & & NOS & $07 / 03 / 10$ & $\mathrm{MN}-16$ & 7 & 5.36 & B \\
\hline AP & $06 / 18 / 10$ & UAP-5 & 5 & 5.02 & & NOS & $07 / 03 / 10$ & $\mathrm{MN}-18$ & 26 & 1.65 & $\mathrm{~N}$ \\
\hline AP & $06 / 19 / 10$ & UAP-2 & 3 & 4.19 & $\mathrm{~N}+\mathrm{P}$ & SM & $07 / 10 / 08$ & $C-55$ & 4 & 5.41 & $\mathrm{~N}, \mathrm{~F}$ \\
\hline SIS & 06/17/09 & $\mathrm{CN}-2$ & 3 & 3.89 & & SM & $07 / 23 / 08$ & MN-6 & 5 & 6.13 & $\mathrm{~N}, \mathrm{~F}$ \\
\hline SMS & $07 / 05 / 08$ & $\mathrm{CN}-6$ & 7 & 5.12 & & SM & $07 / 28 / 08$ & $70 m-36$ & 5 & 6.75 & \\
\hline SMS & $06 / 20 / 09$ & CNN-6 & 32 & 4.33 & & SM & $07 / 06 / 09$ & XB2-4 & 4 & 3.92 & \\
\hline SMS & $06 / 20 / 10$ & $\mathrm{CN} 8$ & 7 & 3.24 & $\mathrm{~N}+\mathrm{P}$ & SM & 07/09/09 & $70 \mathrm{~m} 41$ & 4 & 4.15 & $\mathrm{~N}+\mathrm{P}$ \\
\hline SMS & $06 / 23 / 10$ & CNN 4 & 5 & 2.86 & $\mathrm{~N}+\mathrm{P}$ & SM & $06 / 30 / 10$ & $70 \mathrm{~m}-40$ & 5 & 4.59 & $\mathrm{~N}+\mathrm{P}$ \\
\hline SOS & $06 / 21 / 10$ & CN 17 & 3 & 5.58 & & SM & $07 / 02 / 10$ & MN-9 & 5 & 5.08 & CF, B \\
\hline SOS & 06/18/09 & $\mathrm{CN}-12$ & 5 & 6.44 & & SM & $07 / 09 / 10$ & $70 \mathrm{~m}-50$ & 36 & -1.32 & $\mathrm{~N}+\mathrm{P}$ \\
\hline SOS & $06 / 24 / 09$ & SB-1 & 5 & 6.16 & & SM & $07 / 10 / 10$ & 70 m-39 & 5 & 5.18 & $\mathrm{~N}$ \\
\hline $\mathbf{P}$ & $06 / 25 / 10$ & NP 9 & 6 & 3.77 & $\mathrm{~N}+\mathrm{P}$ & NMS & $07 / 12 / 08$ & SL-8 & 4 & 5.94 & $\mathrm{~N}, \mathrm{~F}$ \\
\hline $\mathbf{P}$ & $07 / 19 / 08$ & NP-11 & 3 & 4.26 & $\mathrm{~N}, \mathrm{~F}$ & NMS & $07 / 26 / 08$ & SL-14 & 6 & 6.57 & $\mathrm{~N}, \mathrm{~F}$ \\
\hline MNMS & $07 / 14 / 08$ & NP-7 & 7 & 5.21 & $\mathrm{~N}, \mathrm{~F}$ & NMS & $07 / 27 / 08$ & $70 m-53$ & 7 & 6.77 & \\
\hline MNMS & $06 / 22 / 09$ & NP-7 & 7 & 5.25 & $\mathrm{~N}^{*}$ & NMS & $07 / 08 / 09$ & $70 \mathrm{~m} 58$ & 10 & 3.30 & $\mathrm{~N}+\mathrm{P}$ \\
\hline MNMS & $07 / 10 / 09$ & $70 m-25$ & 6 & 4.67 & & NMS & $07 / 06 / 10$ & ML-3 & 7 & 5.21 & \\
\hline MNMS & $07 / 11 / 10$ & $70 m-25$ & 3 & 6.53 & & NMS & $07 / 07 / 10$ & SL 11 & 6 & 5.68 & B \\
\hline MNMS & $07 / 11 / 10$ & $70 \mathrm{~m}-25$ & 28 & -0.30 & B & NMS & $07 / 07 / 10$ & SL 11 & 33 & -1.20 & \\
\hline MNIS & $06 / 24 / 10$ & NP 1 & 4 & 3.62 & $\mathrm{~N}+\mathrm{P}$ & NMS & $07 / 08 / 10$ & $\mathrm{BN}-3$ & 5 & 5.69 & \\
\hline MNIS & $07 / 01 / 10$ & MN-1 & 5 & 3.52 & $\mathrm{~N}+\mathrm{P}$ & NMS & $07 / 08 / 10$ & $\mathrm{BN}-3$ & 30 & -1.22 & \\
\hline NOS & $07 / 18 / 08$ & NP-14 & 5 & 7.41 & $\mathrm{~N}, \mathrm{~F}$ & NMS & $07 / 09 / 10$ & $70 m-51$ & 6 & 6.04 & \\
\hline NOS & $07 / 15 / 08$ & NP-14 & 4 & 7.32 & $\mathrm{~N}, \mathrm{~F}$ & NMS & $07 / 06 / 10$ & ML-3 & 7 & 5.21 & $\mathrm{~N}$ \\
\hline NOS & $07 / 20 / 08$ & LS1-6 & 5 & 7.47 & $\mathrm{~N}, \mathrm{~F}$ & NIS & $07 / 09 / 08$ & $\mathrm{MN}-3$ & 3 & 3.31 & $\mathrm{~N}$ \\
\hline NOS & $07 / 22 / 08$ & P14-2 & 7 & 7.07 & $\mathrm{~N}, \mathrm{~F}$ & NIS & $07 / 11 / 08$ & $W-4 b$ & 4 & 4.53 & $\mathrm{~N}, \mathrm{~F}$ \\
\hline NOS & $07 / 24 / 08$ & $\mathrm{MN}-12$ & 7 & 6.24 & $\mathrm{~N}, \mathrm{~F}$ & NIS & $07 / 01 / 09$ & MN-3 & 2 & 2.27 & $\mathrm{~N}^{*}$ \\
\hline NOS & $07 / 25 / 08$ & MN-19 & 9 & 7.90 & $\mathrm{~N}, \mathrm{~F}$ & OSN & 06/23/09 & NP-15 & 4 & 6.40 & $\mathrm{~N}^{*}$ \\
\hline NOS & 07/03/09 & MN-19 & 10 & 6.03 & & OSN & 06/26/09 & P14-7 & 3 & 5.86 & $\mathrm{~N}+\mathrm{P}$ \\
\hline NOS & 06/29/09 & XB16 & 3 & 6.49 & $\mathrm{~N}^{*}$ & OSN & $06 / 28 / 10$ & P14N-10 & 10 & 5.77 & $\mathrm{~N}+\mathrm{P}$ \\
\hline NOS & $07 / 04 / 09$ & $X-6$ & 2 & 5.50 & $\mathrm{~N}^{*}$ & OSN & $06 / 29 / 10$ & TR3 & 5 & 6.22 & $\mathrm{~N}$ \\
\hline NOS & $07 / 05 / 09$ & XB2-12 & 2 & 6.34 & & OSN & $07 / 21 / 08$ & P14-4.5 & 7 & 7.72 & $\mathrm{~N}, \mathrm{~F}$ \\
\hline NOS & $06 / 26 / 10$ & TD2 & 4 & 5.86 & $\mathrm{~N}+\mathrm{P}$ & OSN & 06/25/09 & SB-7 & 5 & 6.35 & \\
\hline NOS & $06 / 27 / 10$ & SB-5 & 4 & 5.44 & $\mathrm{~N}+\mathrm{P}$ & OSSE & 06/19/09 & $\mathrm{CN}-20$ & 7 & 6.31 & $\mathrm{~N}$ \\
\hline NOS & $07 / 03 / 10$ & $\mathrm{MN}-16$ & 7 & 5.36 & $\mathrm{~N}+\mathrm{P}$ & OSSE & $07 / 06 / 08$ & PIT-1 & 6 & 7.09 & $\mathrm{~N}$ \\
\hline NOS & $07 / 03 / 10$ & MN-18 & 26 & 1.65 & B & OSSE & $07 / 07 / 08$ & sta21 & 5 & 6.92 & \\
\hline NOS & $07 / 04 / 10$ & TM4 & 35 & 1.67 & B & & & & & & \\
\hline NOS & $07 / 05 / 10$ & ML-13 & 3 & 5.97 & & & & & & & \\
\hline
\end{tabular}


usual to run incubations with and without nutrient addition. In situ phytoplankton growth rate, $\mu$, is estimated from the incubation without added nutrients and, if nutrient limitation is important, $g$ can be determined from NGR and $\mu$ in the incubations with added nutrients.

To evaluate this, some, but not all, incubations were conducted with and without the addition of nutrients. In 2008, nutrient additions were $5 \mu \mathrm{M} \mathrm{N}$ as $\mathrm{NaNO}_{3}$. Because inconsistent results were observed with the addition of nitrate alone, different nutrient additions were tried in subsequent years. In 2009, nutrient additions were as $5 \mu \mathrm{M} \mathrm{N}$ as $\mathrm{NH}_{4} \mathrm{Cl}$, and in 2010 nutrient additions were $5 \mu \mathrm{M} \mathrm{N}$ as $\mathrm{NaNO}_{3}$ combined with $0.3 \mu \mathrm{M} \mathrm{P}$ as $\mathrm{Na}_{2} \mathrm{HPO}_{4}$. These additions are similar to those used by Strom and Fredrickson (2008) in earlier experiments in the Bering Sea which found no difference between $\mathrm{N}$ addition as $\mathrm{NH}_{4} \mathrm{Cl}$ and $\mathrm{NaNO}_{3}$.

All tubing, carboys, filter cartridges and incubation bottles were cleaned with $10 \% \mathrm{HCl}$, and rinsed three or more times with deionized water, and then rinsed with filtered seawater prior to use and between experiments (Landry, 1993). As mentioned earlier, in "mixed layer" experiments, water was collected with 30 L Niskin bottles on a CTD rosette from the depth corresponding to 55\% surface irradiance level and in "DCM" experiments water was collected from the depth of chlorophyll fluorescence maximum. Seawater was gently siphoned (using silicone tubing) from Niskin bottles into black plastic covered polycarbonate carboys in the CTD bay. During siphoning, water was prescreened through a $200 \mu \mathrm{m}$ Nitex mesh to remove larger zooplankton. This prescreened "whole seawater" (WSW) contained phytoplankton and microzooplankton, however when phytoplankton $>200 \mu \mathrm{m}$ (long diatom chains and large colonial phytoplankton) were present, the pre-screening removed them. Thus, the "WSW" contains a variable fraction of the total in situ chlorophyll. Filtered seawater (FSW) was prepared using gravity filtration and $0.2 \mu \mathrm{m}$ pore size sterile Pall Capsule Filters. Treatments consisted of $100 \%$ WSW and diluted whole seawater. In early experiments $5 \%$ WSW was used for the diluted treatments (95\% FSW), but in low chlorophyll waters it was difficult to obtain consistent chlorophyll measurements due to the low chlorophyll in the diluted treatment. A switch was made to 20\% WSW (80\% FSW and 20\% WSW) when in situ chlorophyll levels were low. Silicon tubing was used to gently transfer, without bubbling, water (WSW or diluted seawater) from 201 polycarbonate carboys to triplicate 11 polycarbonate incubation bottles. If a nutrient addition series was included in an experiment, nutrient stock solution was added with a micropipette directly to triplicate WSW and diluted WSW incubation bottles.

At the beginning of each experiment, triplicate samples for chlorophyll (in effect, $<200 \mu \mathrm{m}$ chlorophyll because of the prescreening) were taken from the WSW and diluted seawater carboys. Samples for microzooplankton and Phaeocystis enumeration were siphoned directly from the Niskin bottles into $125 \mathrm{ml}$ amber bottles and fixed with acid Lugol's solution as described (Stoecker et al., this issue). In mixed layer experiments (Table 1), the triplicate bottles for each treatment were incubated on deck in flowing sea-water with neutral density screening to approximate $55 \%$ surface irradiance. In DCM experiments, the bottles were incubated in the dark on ice in a cold room (Table 1). At the end of the incubations, chlorophyll samples were taken from each bottle. Chlorophyll samples were filtered onto $25 \mathrm{~mm} \mathrm{GF/F}$ filters using gentle vacuum filtration, extracted in $90 \%$ acetone at $-20{ }^{\circ} \mathrm{C}$ for $24 \mathrm{~h}$, and then analyzed at sea with a pre-calibrated fluorometer (Turner Designs TD-700) (method modified from Parsons et al. (1984)). Total chlorophyll $a$ for unscreened samples from the same stations and depths was available from the core measurements or from the primary production study (Lomas et al., 2012).

Chlorophyll $a$ was used as a proxy for phytoplankton biomass. The intrinsic growth rate of phytoplankton $\left(\mu, \mathrm{d}^{-1}\right)$ was calculated from the change in chlorophyll during incubations without and with added nutrients. Similarly, the net growth rate (NGR) of phytoplankton in the presence of microzooplankton grazing was calculated without and with added nutrients (Landry, 1993; Olson and Strom, 2002). Mortality due microzooplankton grazing, $g$, was calculated as $\mu$-NGR. The fraction of phytoplankton growth grazed per day was estimated as $g / \mu$. Daily ingestion $(I)$ of phytoplankton biomass ( $\mu \mathrm{g} \mathrm{Cl}^{-1} \mathrm{~d}^{-1}$ ) was estimated from chlorophyll consumption using a $\mathrm{C}$ : $\mathrm{Chl}$ ratio of 50 for the Bering Sea (Lomas et al., 2012) as $I=(\mathrm{Chl} \mathrm{a})(50)(\mathrm{g})$. Assuming a gross growth efficiency of $35 \%$ for strictly heterotrophic microzooplankton, secondary production based on herbivory was estimated (Landry and Calbet, 2004).

\subsection{Variable fluorescence measurements}

In several studies, insignificant grazing coefficients and/or statistically significant "negative" microzooplankton grazing rates have been reported from a proportion of the stations in the Bering Sea and also from other sub-Arctic and Arctic seas (Olson and Strom, 2002; Strom and Fredrickson, 2008; Calbet et al., 2011; Sherr et al., 2013). "Negative grazing" is impossible, but calculation of negative " $g$ " results when the $\mu$ of phytoplankton in the diluted treatment is lower than in the WSW. Lower growth of phytoplankton in the diluted treatments than in the WSW is usually attributed to lack of regenerated nutrients due to low numbers of micrograzers in the diluted treatments. However, nutrient addition usually did not eliminate the effect in our experiments. To explore the possibility that dilution itself, or chemicals released from plankton into the dilution water during preparation of FSW, have a negative effect on phytoplankton, the ratio of variable to maximum fluorescence (Fv/Fm) of phytoplankton in the undiluted WSW and diluted treatments was determined. Fv/Fm ratio is a measure of the potential maximum quantum yield of PSII in phytoplankton. A decrease in the ratio of $\mathrm{Fv} / \mathrm{Fm}$ is usually associated with a reduction in ability of the cells to photosynthesize. From an ecological perspective, a decrease in the $\mathrm{Fv} / \mathrm{Fm}$ ratio has often been used as an indicator of physiological stress. Fv/Fm was measured after incubation of subsamples in the dark for $\sim 1 \mathrm{~h}$ in a Automated Laser Fluorometer (ALF) (Chekalyuk and Hafez, 2008). A more detailed description of the instrument and the measurement protocols is available in Goes et al. (this issue). Fv/ Fm was measured in samples from the triplicate incubation bottles in the 100\%WSW, 20\%WSW, 100\%WSW+nutrients, $20 \%$ WSW + nutrients treatments at the end of the $24 \mathrm{~h}$ incubations in mixed layer experiments at 14 stations in 2008 (Table 1). Samples were collected in $500 \mathrm{ml}$ amber glass bottles, and stored in the dark for about $30 \mathrm{~min}$, to minimize the impacts of nonphotochemical quenching before analysis in the ALF.

\subsection{Enumeration of P. pouchettii}

The bloom forming phytoplankter $P$. pouchettii has been associated with inhibition of grazing in dilution experiments (Calbet et al., 2011). To determine if low grazing coefficients were associated with abundance of Phaeocystis cells, this phytoplankter was enumerated in whole water samples fixed with acid Lugol's (refer to Stoecker et al. (this issue)) using a 1-ml capacity Sedgwick-Rafter counting chamber at $400 \times$ magnification. However, the actual density of $P$. pouchettii cells in the incubations must have been lower, because colonies $>200 \mu \mathrm{m}$ in size were removed by screening to remove copepods before setting up the dilution experiment incubations. 


\subsection{Statistical analyses}

Analysis of variance (ANOVA) was used to test statistical significance $(p<0.05)$ of differences between the net growth rate of phytoplankton in the WSW and diluted treatments in an experiment. Significantly higher phytoplankton net growth rates in the diluted treatment than in the WSW treatment would indicate that grazing was significant. ANOVA was used to test for differences in coefficients from incubations with and without addition of nutrients, mixed layer versus DCM incubations, and among domains. Two-tailed $T$-tests were used to compare variable fluorescence measurements between diluted and undiluted treatments within an experiment. Pearson productmoment correlation tested for statistically significant associations between factors, with the square of the correlation coefficient, $r^{2}$, a measure of the variation in one variable determined by the variation in the other variable. If the data did not fulfill the assumptions for ANOVA, we applied appropriate transformations. ANOVA on ranks was used if data still did not meet the assumptions. Sigmaplot version 9.0 (Systat Software, Inc.) was used for all statistical analyses.

\section{Results}

\subsection{Effect of nutrient additions}

The results of paired dilution experiments conducted with and without the addition of nutrients were compared (Table 2). In

Table 2

Effect of nutrient additions (+Nuts) on phytoplankton growth $(\mu)$ and microzooplankton grazing $(g)$ in dilution experiments, mixed layer, summer, Eastern Bering Sea 2008, 2009, 2010. Mean (SD).

\begin{tabular}{llllll}
\hline Year & $\begin{array}{l}\text { Number of } \\
\text { experiments }\end{array}$ & & Control & + Nuts $^{\mathrm{a}}$ & $\begin{array}{l}\text { Control } \\
\text { vs. nuts }\end{array}$ \\
\hline 2008 & 21 & $\mu$ & $0.31(0.178)$ & $0.31(0.204)$ & ns \\
& & $g$ & $0.24(0.237)$ & $0.11(0.224)$ & $*$ \\
2009 & 5 & $\mu$ & $0.17(0.178)$ & $0.18(0.159)$ & ns \\
& & $g$ & $0.12(0.114)$ & $0.08(0.113)$ & ns \\
2010 & \multirow{2}{*}{15} & $\mu$ & $0.28(0.157)$ & $0.36(0.165)$ & $* *$ \\
& & $g$ & $0.21(0.125)$ & $0.21(0.138)$ & ns \\
\hline
\end{tabular}

\footnotetext{
$* p \leq 0.05$

$* * * 0.01$

a 2008: $5 \mu \mathrm{M} \mathrm{N}$ as sodium nitrate; 2009: $5 \mu \mathrm{M} \mathrm{N}$ as $\mathrm{NH}_{4} \mathrm{Cl}$; 2010: $5 \mu \mathrm{M} \mathrm{N}$ as sodium nitrate $+0.3 \mu \mathrm{M}$ P as sodium phosphate.

${ }^{\mathrm{b}}$ Repeated measures ANOVA: ns=non-significant.
}

calculating means and standard deviations, data from all paired incubations, whether or not grazing was statistically significant were included; " 0 " was substituted for negative " $g$ " values in calculating means. In 2008, 21 comparative experiments were conducted, with and without the addition of $5 \mu \mathrm{M}$ nitrogen as sodium nitrate. Mean phytoplankton growth rates $\left(\mu, \mathrm{d}^{-1}\right)$ in the control (no nutrient addition) and nutrient addition treatments were similar, however grazing coefficients $\left(g, d^{-1}\right)$ were significantly lower in the nutrient treatments (Table 2). In 2009, five comparative experiments were conducted in which the $5 \mu \mathrm{M}$ nitrogen nutrient treatment was attained using ammonium chloride. The effects on phytoplankton growth and grazing were both non-significant (Table 2). In 2010, 15 experiments were conducted in which the nutrient treatment was addition of $5 \mu \mathrm{M}$ nitrogen as sodium nitrate in combination with $0.35 \mu \mathrm{M}$ phosphate as sodium phosphate. The nutrient treatment significantly increased mean phytoplankton growth but not estimation of microzooplankton grazing (Table 2). Nutrient additions are done to prevent greater nutrient limitation in diluted than in undiluted treatments in microzooplankton grazing experiments; greater nutrient limitation in diluted treatments would result in an underestimation of microzooplankton grazing (refer to Section 2.2) (Landry, 1993; Strom and Fredrickson, 2008). However, microzooplankton grazing coefficients were the same or lower with nutrient addition than without nutrient addition (Table 2), indicating that there was no reason to use data from the nutrient addition treatments to estimate microzooplankton grazing in our experiments. Based on these results, microzooplankton grazing is reported based upon the no addition dilution series. Olson and Strom (2002) also noted that nutrient enrichment sometime results in a decrease in phytoplankton growth rates in dilution experiments in the Bering Sea.

\subsection{Phytoplankton growth, microzooplankton grazing, ingestion and production in the mixed layer}

The $<200 \mu \mathrm{m}$ fraction of the total chlorophyll ranged from an average of $69 \%$ at the Off Shelf, $79-90 \%$ at the Outer Shelf stations, $41-98 \%$ at the Middle Shelf stations, $77 \%$ at the Inner Shelf stations and $74 \%$ at the Alaska Peninsula stations (Table 3). Grazing coefficients were greater than " 0 " in $61 \%$ of the 59 dilution experiments conducted with mixed layer assemblages (Table 3 ). To avoid biasing the data against low growth and grazing rates, all coefficients were included, whether or not they were significant,

Table 3

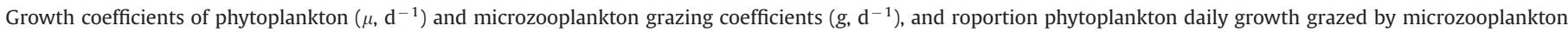
$(g / \mu)$. Mixed layer data for 2008, 2009, 2010 combined by region. Mean (SD). For $g$ and $\mu$, mean of all incubations without added nutrients, but "0" used for negative $g$.

\begin{tabular}{|c|c|c|c|c|c|c|}
\hline Region & Chl $a<200 \mu \mathrm{m}\left(\mu \mathrm{g} \mathrm{l}^{-1}\right)$ & $\%$ Chl $a<200 \mu \mathrm{m}$ & Incubation PAR $\left(\mu \mathrm{E} \mathrm{s}^{-1} \mathrm{~m}^{-2}\right)$ & $\mu$ & $g$ & $g / \mu$ \\
\hline \multicolumn{7}{|l|}{ Off Shelf } \\
\hline Southeast $\left(n=3,1^{*}\right)$ & $0.77(0.44)$ & nd & $742(300.1)$ & $0.24(0.16)$ & $0.16(0.16)$ & 0.67 \\
\hline North $\left(n=6,4^{*}\right)$ & $0.60(0.54)$ & $69(32)$ & $278(119.3)$ & $0.30(0.12)^{a}$ & $0.23(0.09)^{\mathrm{a}}$ & $0.77^{\mathrm{a}}$ \\
\hline \multicolumn{7}{|l|}{ Outer Shelf } \\
\hline South $\left(n=3,2^{*}\right)$ & $0.79(0.22)$ & $90(14)$ & $210(151.6)$ & $0.32(0.20)$ & $0.25(0.15)$ & 0.78 \\
\hline North $\left(n=14,9^{*}\right)$ & $0.89(0.64)$ & $79(14)$ & $328(141.5)$ & $0.25(0.24)$ & $0.19(0.12)$ & 0.76 \\
\hline \multicolumn{7}{|l|}{ Middle Shelf } \\
\hline South $\left(n=3,2^{*}\right)$ & $0.38(0.22)$ & $98(2)$ & $517(146)$ & $0.27(0.11)$ & $0.24(0.06)$ & 0.89 \\
\hline Mid-North $\left(n=4,3^{*}\right)$ & $0.40(0.35)$ & $41(49)$ & $241(41.0)$ & $0.08(0.62)$ & $0.19(0.20)$ & 1.56 \\
\hline St. Matthews $\left(n=8,6^{*}\right)$ & $0.52(0.52)$ & $62(1)$ & $344(184.5)$ & $0.25(0.15)$ & $0.28(0.22)$ & 1.17 \\
\hline North $\left(n=8,4^{*}\right)$ & $0.33(0.41)$ & $97(25)$ & $440(188.4)$ & $0.24(0.21)$ & $0.34(0.28)$ & 1.42 \\
\hline $\begin{array}{l}\text { Inner Shelf } \\
\text { (South, Mid-North and North combined) }\left(n=6,3^{*}\right)\end{array}$ & $0.47(0.28)$ & $77(50)$ & $263(116.2)$ & $0.19(0.14)$ & $0.22(0.25)$ & 1.16 \\
\hline AK Peninsula $\left(n=4,2^{*}\right)$ & $0.71(0.47)$ & $74(30)$ & 334 & $0.45(0.23)$ & $0.27(0.22)$ & 0.60 \\
\hline
\end{tabular}

* Number of experiments in which $g$ was statistically significant $(p<0.05)$.

${ }^{a}$ Calculated without one outlier replicate in one experiment. $\mathrm{Nd}=$ no data. 
in our estimates of average rates. Exclusion of "0" or nonsignificant coefficients can inflate regional and global estimates of both phytoplankton growth and microzooplankton grazing (Landry and Calbet, 2005). However, negative grazing coefficients were replaced with " 0 " in averaging because negative grazing is not possible; calculation of a negative " $g$ " occurs when phytoplankton net growth is lower in the diluted treatment than undiluted treatment, and there are several reasons for this phenomenon (refer to Section 3.4). In these instances, the phytoplankton growth rate in WSW was substituted for the rate in the diluted treatment.

If data from the Mid-North region are excluded, average phytoplankton growth coefficients were in the range of 0.19$0.45 \mathrm{~d}^{-1}$ (Table 3). The average phytoplankton growth coefficient for the mid-north Middle Shelf was low (Table 3) because of one experiment with a significant negative growth rate $(\mu=-0.80)$; without this one experiment, the average of the regional growth rates was $0.37 \mathrm{~d}^{-1}$. The average phytoplankton growth rate in the Alaska Peninsula region appeared to be higher than rates in the other areas, but differences among regions were not statistically significant (1-WAY ANOVA, $p>0.05$ ). Likewise, estimates of average microzooplankton grazing were relatively similar across regions, ranging from 0.16 to $0.34 \mathrm{~d}^{-1}$ (Table 3 ) and differences among regions were not statistically significant (1-WAY ANOVA, $p>0.05$ ). Correlations between $\mu$ or $g$ and mixed layer water temperature, inorganic nutrients (phosphate, silicate, nitrate, ammonium) and estimated total PAR for incubations (data not shown) were not statistically significant (Pearson Product Moment Correlation; $p>0.05$ ). Both microzooplankton grazing and phytoplankton growth coefficients correlated negatively with total chlorophyll $a$, but the coefficients of determination $\left(r^{2}\right)$ were low (Fig. 2A and B). Microzooplankton grazing ( $<200 \mu \mathrm{m}$ fraction) was not correlated with the biomass of $20-200 \mu \mathrm{m}$ ciliate and dinoflagellate microzooplankton $(p>0.05)$ (data not shown). Microzooplankton grazing was also not correlated with abundance of Phaeocystis cells ( $p>0.05)$ (data not shown).

The proportion of phytoplankton growth grazed by the $<200 \mu \mathrm{m}$ fraction was calculated as " $g / \mu$ " from the average " $g$ " and " $\mu$ " for regions (Table 3). Estimates for individual incubations could not be made because of negative or zero coefficients. Estimated average proportion of phytoplankton growth in the $<200 \mu \mathrm{m}$ fraction grazed by phytoplankton appeared to vary among regions (Fig. 3). In the Off Shelf and Outer Shelf regions, microzooplankton grazing consumed $67-78 \%$ of phytoplankton growth but on the Middle Shelf and Inner Shelf (with the exception of the south Middle Shelf) microzooplankton grazing coefficients were greater than phytoplankton growth rates in the mixed layer (Fig. 3 and Table 3).

Estimated phytoplankton carbon ingestion by microzooplankton was $11.0 \mu \mathrm{g}$ carbon $\mathrm{l}^{-1} \mathrm{~d}^{-1}$ in the Alaska Peninsula region, 8.2 Off Shelf, 7.7 on the Outer Shelf, 4.7 on the Middle Shelf and $4.4 \mathrm{~d}^{-1}$ on the Inner Shelf, with differences among regions not statistically significant (1 Way ANOVA, $p>0.05$ ) (Fig. 4). Assuming that all microzooplankton were strictly heterotrophic and a gross growth efficiency of $35 \%$, the estimated secondary production of microzooplankton in the mixed layer was $3.8 \mu \mathrm{g}$ carbon $\mathrm{l}^{-1} \mathrm{~d}^{-1}, 2.9,2.7,1.6$, and 1.5 for the Alaska Peninsula, Off Shelf, Outer Shelf, Middle Shelf and Inner Shelf regions, respectively. However, because of the prevalence of mixotrophy among the ciliates, it is possible that average gross growth efficiently of the microzooplankton was higher and thus secondary production higher (Stoecker et al., this issue).

\subsection{Microzooplankton grazing, ingestion and production in the DCM}

Dilution grazing experiments were conducted with deep chlorophyll maximum assemblages at four stations in 2010, with DCM experiments paired with mixed layer incubations at the same station
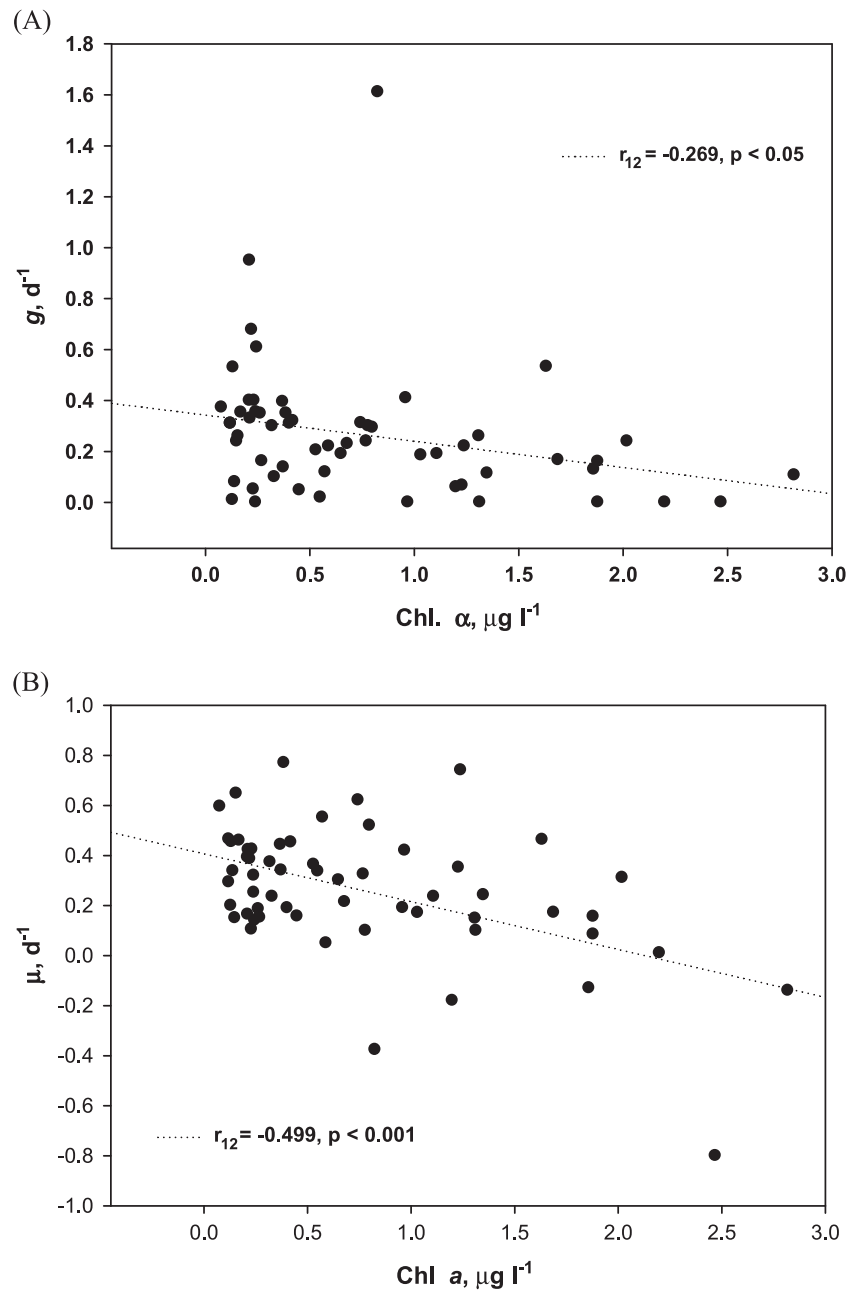

Fig. 2. Microzooplankton grazing coefficients $\left(g, d^{-1}\right)(A)$ and phytoplankton growth $\left(\mu, \mathrm{d}^{-1}\right)$ (B) vs. chlorophyll $a$, mixed layer, Eastern Bering Sea. Data for summers 2008, 2009 and 2010 were included; no nutrient addition treatments only. Product moment correlation coefficients $\left(r_{12}\right)$ are shown as well as their statistical significance. The coefficient of determination, $r^{2}$, was 0.072 and 0.236 in $\mathrm{A}$ and $\mathrm{B}$, respectively, indicating that variation in chlorophyll only determined a small proportion of the variation in grazing and phytoplankton growth coefficients.

(Table 4). Irradiance levels and water temperatures were low in the DCM; experiments were incubated in the dark on ice $\left(\sim 0{ }^{\circ} \mathrm{C}\right)$ in a cold room (Table 4). Incubation temperatures were $0.3-1.2{ }^{\circ} \mathrm{C}$ higher than in situ DCM water temperatures, which may have resulted in slightly elevated grazing. Grazing coefficients in the DCM ranged from $\sim 0$ to $0.70 \mathrm{~d}^{-1}$ and in two out of four DCM incubations, the grazing coefficients were significant $(p<0.05)$ (Table 4$)$. It is interesting that in paired mixed layer and DCM incubations, the DCM grazing coefficients were similar in magnitude to the mixed layer coefficients (Table 4). However, because of the higher phytoplankton biomass in the DCM than in the mixed layer, the estimated ingestion of phytoplankton carbon by microzooplankton in the DCM was higher than in the mixed layer (Fig. 5). Assuming similar C:Chl ratios and gross growth efficiencies for microzooplankton in the mixed layer (refer to Section 3.2) and the DCM, microzooplankton production can be compared for the stations with statistically significant grazing in both layers (Table 4). At station SL-11, the calculated microzooplankton production in the mixed layer was 5.0 and in the DCM $13.2 \mu \mathrm{g} \mathrm{Cl}^{-1} \mathrm{~d}^{-1}$. At station BN-3, the calculated microzooplankton production in the mixed layer was 0.5 and in the DCM $3.1 \mu \mathrm{g} \mathrm{Cl}^{-1} \mathrm{~d}^{-1}$. (Production estimates were not made for experiments in which grazing was not statistical significant (Table 4).) 


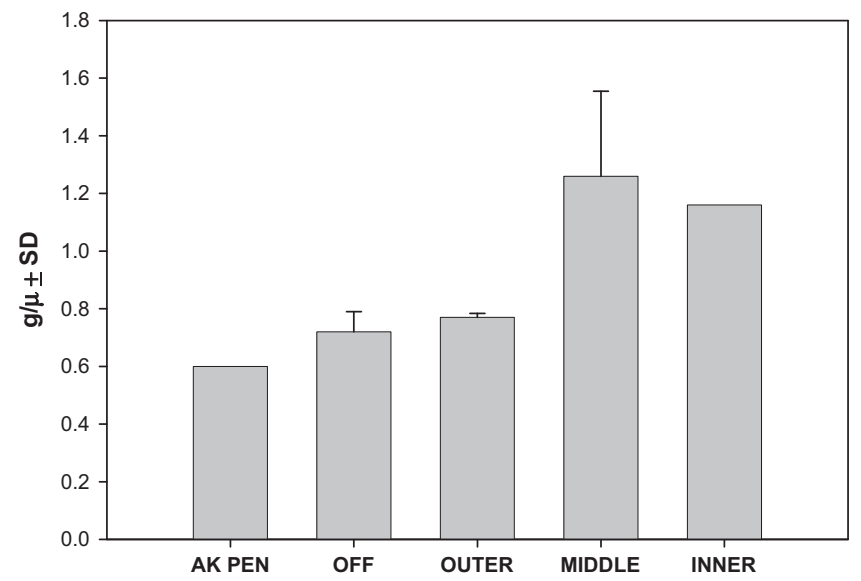

Fig. 3. Estimated fraction of phytoplankton daily growth consumed by microzooplankton grazing $(g / \mu)$ in the mixed layer, Eastern Bering Sea, summers 2008, 2009, 2010 (no nutrient addition treatments only). For each region, mean grazing ( $g$ ) and growth $(\mu$ ) coefficients (Table 3 ) were used to calculate a regional "g/u" (refer to Section 3.2). For each of the domains (OFF, OUTER, MIDDLE) with data for several regions (Table 3 ), the regional estimates were averaged to obtain a domain mean " $g / \mu$ ". For the domain (AK PEN) with one region (Table 3 ) and for the domain (INNER) with data for only a few stations (Table 3), data from individual stations were used to calculate average $g$ and $u$ for the domain and then these averages were used to calculate the $g / u$ for the domain. AK PEN=Alaska Peninsula region; $\mathrm{OFF}=$ off shelf; OUTER $=$ outer shelf; MIDDLE $=$ middle shelf; INNER $=$ inner shelf or coastal. Data combined for summers 2008, 2009, and 2010. Error bars indicate standard deviation for OFF, OUTER, and MIDDLE domains.

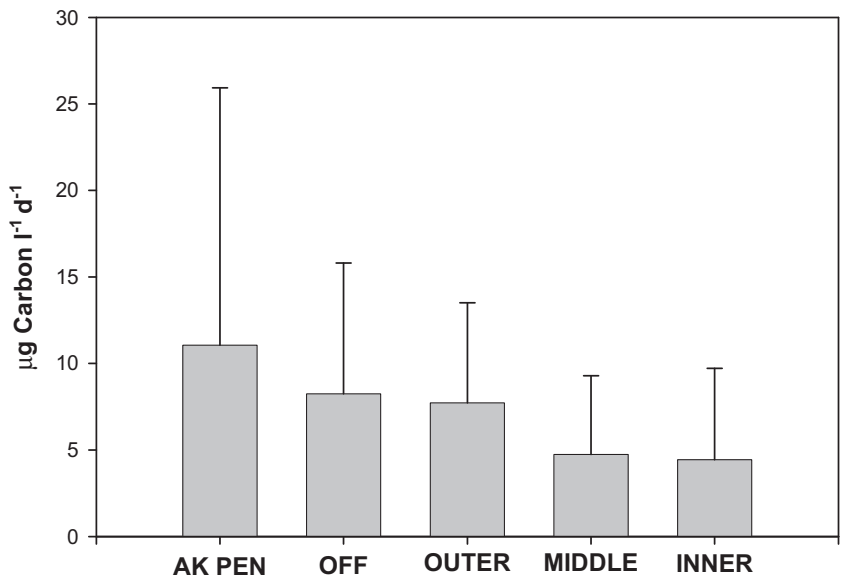

Fig. 4. Estimated microzooplankton ingestion of phytoplankton carbon in the mixed layer, Eastern Bering Sea, summers 2008, 2009, 2010. Estimates of ingestion from stations within a domain were averaged. AK PEN=Alaska Peninsula region; $\mathrm{OFF}=$ off shelf; OUTER $=$ outer shelf; MIDDLE $=$ middle shelf; INNER $=$ inner shelf or coastal. Error bars indicate standard deviation.
Microzooplankton secondary production in the DCM on a per liter basis may be several fold higher than in the mixed layer.

\subsection{Non-significant and "negative" grazing coefficients and Fv/Fm}

In $39 \%$ of our dilution grazing experiments with mixed layer assemblages the grazing coefficients were not statistically significant $(p>0.05)$ and in 3\% of our experiments grazing coefficients were statistically significant, but negative. Estimation of microzooplankton grazing in dilution experiments is based on the assumption that phytoplankton growth rate is the same in diluted and undiluted treatments. To determine if dilution was having a negative effect on the physiology of phytoplankton, and potentially on their growth rates, variable fluorescence (Fv/Fm) was measured in both the undiluted (WSW) and diluted (20\% WSW) treatments at the end of paired incubations with and without added nitrate (Table 1 ). Fv/Fm was significantly lower ( $T$-test, $p<0.05$ ) in the diluted than undiluted treatments in eight out of 14 incubations without added nutrients and in seven out of 14 incubations with added nutrients (Table 5). Fv/Fm was significantly higher $(p<0.05)$ in the diluted treatments with than without added nitrate in three of the 14 experiments (data not shown). In only two experiments did this alleviate the negative effect of dilution on variable fluorescence of phytoplankton (Table 5). Low estimates of microzooplankton grazing coefficient were associated with experiments in which dilution had a large negative effect on Fv/Fm (Fig. 6).

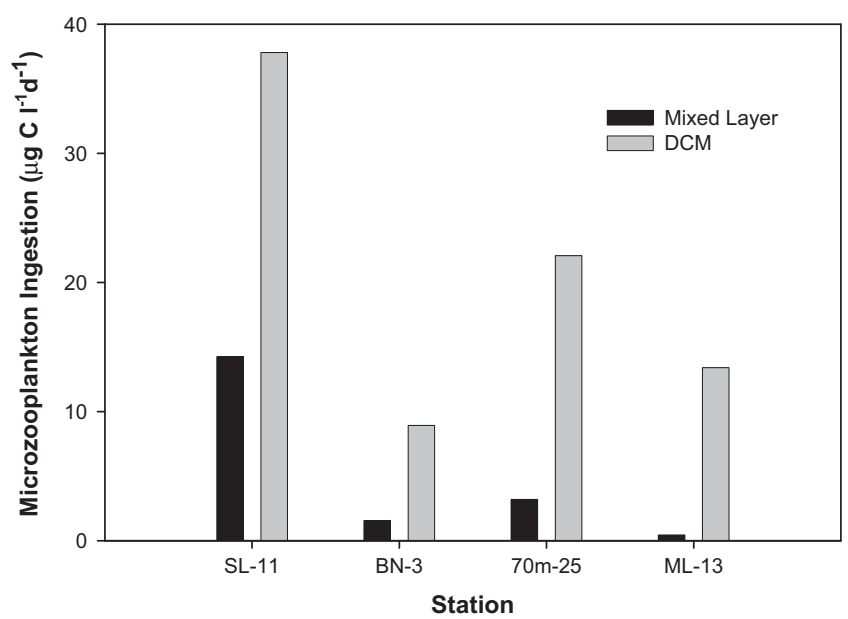

Fig. 5. Comparison of estimated microzooplankton ingestion of phytoplankton carbon, paired mixed layer and DCM experiments, Eastern Bering Sea, summer 2010 .

Table 4

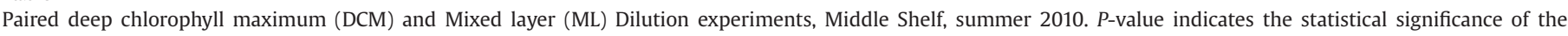
difference between the net growth rate of phytoplankton in the WSW and diluted treatment. ns=non-significant.

\begin{tabular}{|c|c|c|c|c|c|c|c|c|c|}
\hline \multirow[t]{2}{*}{ Domain (region) } & \multirow[t]{2}{*}{ Station } & \multirow{2}{*}{$\begin{array}{l}\text { Sample depth } \\
\text { (m) }\end{array}$} & \multicolumn{2}{|c|}{ Temp. $\left({ }^{\circ} \mathrm{C}\right)$} & \multirow{2}{*}{$\begin{array}{l}\text { Avg. Incub. Irradiance } \\
\mu \mathrm{E} \mathrm{s}^{-1} \mathrm{~m}^{-2}\end{array}$} & \multirow{2}{*}{$\begin{array}{l}\text { Chlorophyll } \\
a\left(t_{0}\right)\left(\mu \mathrm{g} \mathrm{l}^{-1}\right)\end{array}$} & \multirow[t]{2}{*}{$\mu$} & \multirow[t]{2}{*}{$g$} & \multirow{2}{*}{$\begin{array}{l}\text { ANOVA } \\
p \text {-value }\end{array}$} \\
\hline & & & In situ & Incub. & & & & & \\
\hline Middle (10) & SL-11 & $\begin{array}{l}\text { 6-ML } \\
\text { 33-DCM }\end{array}$ & $\begin{array}{r}5.6 \\
-1.2\end{array}$ & $\begin{array}{l}\sim 6 \\
\sim 0\end{array}$ & $\begin{array}{l}347 \\
\text { Dark }\end{array}$ & $\begin{array}{l}0.30 \\
1.08\end{array}$ & $\begin{array}{r}0.16 \\
-1.03\end{array}$ & $\begin{array}{l}0.95 \\
0.70\end{array}$ & $\begin{array}{l}<0.001 \\
<0.001\end{array}$ \\
\hline Middle (10) & $\mathrm{BN}-3$ & $\begin{array}{l}\text { 5-ML } \\
\text { 30-DCM }\end{array}$ & $\begin{array}{r}5.7 \\
-1.2\end{array}$ & $\begin{array}{l}\sim 6 \\
\sim 0\end{array}$ & $\begin{array}{l}524 \\
\text { Dark }\end{array}$ & $\begin{array}{l}0.10 \\
0.85\end{array}$ & $\begin{array}{l}0.29 \\
0.03\end{array}$ & $\begin{array}{l}0.31 \\
0.21\end{array}$ & $\begin{array}{l}<0.01 \\
<0.01\end{array}$ \\
\hline Middle(6) & $70 m-25$ & $\begin{array}{l}\text { 3-ML } \\
\text { 28-DCM }\end{array}$ & $\begin{array}{r}6.5 \\
-0.3\end{array}$ & $\begin{array}{l}\sim 6 \\
\sim 0\end{array}$ & $\begin{array}{l}262 \\
\text { Dark }\end{array}$ & $\begin{array}{l}0.16 \\
1.84\end{array}$ & $\begin{array}{r}0.39 \\
-0.03\end{array}$ & $\begin{array}{l}0.40 \\
0.24\end{array}$ & $\begin{array}{l}<0.05 \\
\text { ns }\end{array}$ \\
\hline Outer (8) & ML-13 & $\begin{array}{l}\text { 3-ML } \\
\text { 35-DCM }\end{array}$ & $\begin{array}{r}6.0 \\
-1.1\end{array}$ & $\begin{array}{l}\sim 6 \\
\sim 0\end{array}$ & $\begin{array}{l}330 \\
\text { Dark }\end{array}$ & $\begin{array}{l}0.11 \\
5.36\end{array}$ & $\begin{array}{l}0.34 \\
0.04\end{array}$ & $\begin{array}{l}0.08 \\
0.05\end{array}$ & $\begin{array}{l}\text { ns } \\
\text { ns }\end{array}$ \\
\hline
\end{tabular}


Table 5

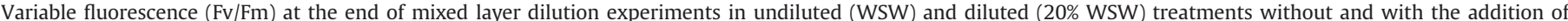
$0.05 \mu \mathrm{M} N$ as sodium nitrate. All experiments conducted in summer 2008. $N=2$ or 3 .

\begin{tabular}{|c|c|c|c|c|c|c|}
\hline \multirow[t]{2}{*}{ Station } & \multicolumn{2}{|c|}{ Mean (SD), no nutrient addition } & \multirow{2}{*}{$\begin{array}{l}T \text {-test } \\
p\end{array}$} & \multicolumn{2}{|c|}{ Mean (SD), nutrient addition } & \multirow{2}{*}{$\begin{array}{l}T \text {-test } \\
p\end{array}$} \\
\hline & WSW & $20 \% W S W$ & & WSW & $20 \% W S W$ & \\
\hline$C-55$ & $0.345(0.0071)$ & $0.357(0.0896)$ & ns & $0.348(0.031)$ & $0.353(0.459)$ & ns \\
\hline$W-4 b$ & $0.237(0.0379)$ & $0.263(0.0752)$ & ns & $0.245(0.028)$ & $0.283(0.031)$ & ns \\
\hline SL-8 & $0.350(0.0433)$ & $0.327(0.0431)$ & ns & $0.353(0.040)$ & $0.426(0.087)$ & ns \\
\hline NP-7 & $0.330(0.0100)$ & $0.232(0.0126)$ & $p<0.05$ & $0.310(0.010)$ & $0.357(0.041)$ & ns \\
\hline NP-14 & $0.183(0.1626)$ & $0.198(0.0775)$ & ns & $0.317(0.063)$ & $0.270(0.020)$ & ns \\
\hline NP-14 & $0.263(0.0115)$ & $0.220(0.0200)$ & $p<0.05$ & $0.268(0.010)$ & $0.267(0.018)$ & ns \\
\hline NP-11 & $0.341(0.0136)$ & $0.315(0.0391)$ & ns & $0.362(0.007)$ & $0.300(0.025)$ & $p<0.05$ \\
\hline LS1-6 & $0.343(0.0152)$ & $0.278(0.0202)$ & $p<0.05$ & $0.345(0.008)$ & $0.265(0.007)$ & $p<0.05$ \\
\hline P14-4.5 & $0.253(0.0144)$ & $0.158(0.0126)$ & $p<0.05$ & $0.268(0.029)$ & $0.183(0.023)$ & $p<0.05$ \\
\hline P14-2 & $0.298(0.0126)$ & $0.233(0.0252)$ & $p<0.05$ & $0.313(0.005)$ & $0.245(0.022)$ & $p<0.05$ \\
\hline MN-6 & $0.280(0.0173)$ & $0.227(0.0058)$ & $p<0.05$ & $0.307(0.011)$ & $0.247(0.005)$ & $p<0.05$ \\
\hline MN-12 & $0.245(0.0071)$ & $0.153(0.0153)$ & $p<0.05$ & $0.273(0.028)$ & $0.150(0.014)$ & $p<0.05$ \\
\hline MN-19 & $0.250(0.0173)$ & $0.183(0.0289)$ & $p<0.05$ & $0.240(0.026)$ & $0.163(0.032)$ & $p<0.05$ \\
\hline SL-14 & $0.263(0.0306)$ & $0.210(0.0346)$ & ns & $0.283(0.064)$ & $0.233(0.010)$ & ns \\
\hline
\end{tabular}

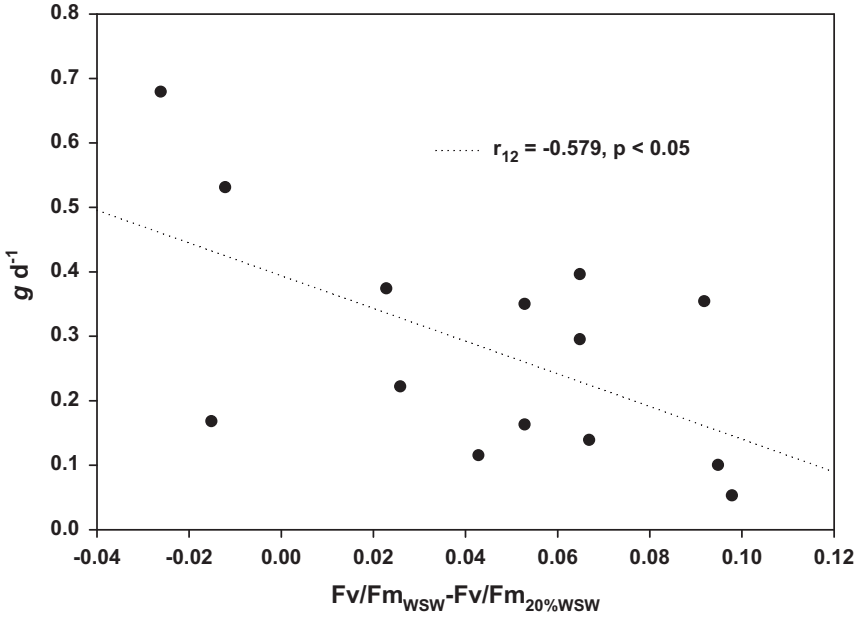

Fig. 6. Estimated microzooplankton grazing coefficients $\left(g, d^{-1}\right)$ vs. the difference in variable fluorescence $(\mathrm{Fv} / \mathrm{Fm})$ between WSW and diluted treatments in an experiment. The product moment correlation coefficient $\left(r_{12}\right)$ and its statistical significance are shown. Low grazing was associated with decreased Fv/Fm in the diluted compared to the whole seawater treatments. The coefficient of determination $\left(r^{2}\right)$ was 0.335 .

\section{Discussion}

During summers of 2008-2010, all "cold years" in the Eastern Bering Sea (Stabeno et al., 2012b), the over-all average mixed layer microzooplankton grazing coefficient was $0.26 \mathrm{~d}^{-1}$, which is quite similar to the average coefficient of $0.29 \mathrm{~d}^{-1}$ observed on the SE shelf by Olson and Strom (2002) during summer 1999, another cold year (Table 6). In 2004, a "warm year" (Ladd and Stabeno, 2012), microzooplankton grazing was low on the SE Shelf (Strom and Fredrickson, 2008) (Table 6). The low grazing in 2004 was probably a response of microzooplankton to poor food quality caused by phytoplankton nutrient limitation due to intense stratification (Strom and Fredrickson, 2008), however "warm" years are not always associated with high stratification on the Bering Sea Shelf (Ladd and Stabeno, 2012), so it is unlikely that summer microzooplankton grazing is predictable from temperature alone. During 2004, phytoplankton growth rates responded strongly to addition of nutrients (Strom and Fredrickson, 2008) but increases in phytoplankton growth in response to nutrient additions were only observed in one year, 2010, in our study (Table 2). Contrary to expectations, nutrient addition sometimes resulted in lower estimates of phytoplankton growth and sometimes microzooplankton grazing. Possible inhibition of growth and grazing due to nutrient addition has been previously reported, but the reasons for inhibition are not understood (Gifford, 1988; Olson and Strom, 2002).

Average microzooplankton grazing coefficients during spring sea ice conditions are $<50 \%$ of summer grazing coefficients (Table 6). The lower grazing coefficients in spring are probably due to a combination of factors including lower ratios of microzooplankton biomass to phytoplankton biomass in spring than in summer (Sherr et al., 2013; Stoecker et al., this issue), differences in size distribution and species composition of phytoplankton (Lomas et al., 2012) and lower water temperatures in spring (Rose and Caron, 2007; Rose et al., 2013).

It is interesting that both the growth rate of phytoplankton $(\mu)$ and microzooplankton grazing $(g)$ was correlated negatively with total chlorophyll $a$ in the mixed layer. Negative or no correlation of growth and grazing coefficients with chlorophyll have also been noted by Olson and Strom (2002), Strom et al. (2007), and Calbet et al. (2011) in northern seas in summer. This is consistent with domination of the phytoplankton by $<5 \mu \mathrm{m}$ cells, and a rate, rather than biomass, controlled production system dependent on nutrient recycling (Lomas et al., 2012). Based on primary production measurements, integrated phytoplankton growth rates $(\mu)$ averaged $0.42 \mathrm{~d}^{-1}$ (SD, 0.17) (Lomas et al., 2012), which is within the wide range of phytoplankton growth rates that we estimated in mixed layer dilution experiments (Table 6). In the north middle and inner domains, the biomass of microzooplankton to phytoplankton was high in summer (Stoecker et al., this issue), consistent with the high ratios of microzooplankton grazing to phytoplankton growth. A confounding factor in estimating phytoplankton growth and microzooplankton grazing from chlorophyll in dilution experiments on the Bering Sea Shelf is the high biomass of plastidic ciliates in summer (Stoecker et al., this issue). The incorporation of phytoplankton chloroplasts into ciliates may result in underestimation of microzooplankton grazing and an overestimate of "phytoplankton" biomass.

Comparison of the spatial distributions of phytoplankton growth, microzooplankton grazing, chlorophyll $a$, variable fluorescence, and phytoplankton composition from the HPLC (Goes et al., this issue) revealed similar patterns among some of the variables and identified the phytoplankton communities associated with different growth and grazing coefficients during summer 2008. High phytoplankton growth $\left(\mu, \mathrm{d}^{-1}\right)$ and moderate microzooplankton grazing $\left(g, d^{-1}\right)$ were measured on the north Middle Shelf, where diatom and cryptophytes patches, probably remnants of spring ice associated blooms, were observed (Fig. 7). Elevated phytoplankton 
Table 6

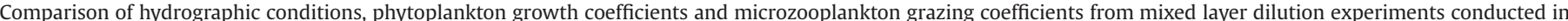

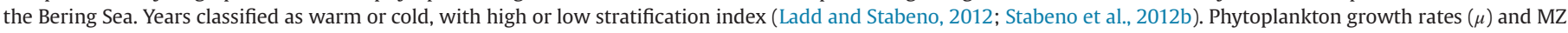
grazing rates $(g)$ per day. Average with SD in parentheses, or range.

\begin{tabular}{|c|c|c|c|c|}
\hline $\begin{array}{l}\text { Cruise dates and hydrographic conditions in } \\
\text { SE Bering Sea }\end{array}$ & Water $\left({ }^{\circ} \mathrm{C}\right)$ & Growth & Grazing & Ref. \\
\hline $\begin{array}{l}\text { July 99: South Bering Sea (Off Shelf and } \\
\text { Outer Shelf) (cold year) }\end{array}$ & $5.3-7.7$ & $0.2-0.6,0.41(n=5)$ & $0.1-0.4,0.27,(n=5)$ & Liu et al. (2002) \\
\hline $\begin{array}{l}\text { July-August 99; SE Bering Sea (cold year } \\
\text { with low stratification index) }\end{array}$ & $5.8-8.4$ & -0.7 to $0.6,0.33(n=13)$ & $0.1-0.5,0.29,(n=13)$ & Olson and Strom (2002) \\
\hline $\begin{array}{l}\text { July-August 04: SE Bering Sea (warm } \\
\text { year with high stratification index) }\end{array}$ & $9.3-13.4$ & $0.0-1.0,0.35(n=18)$ & $0.0-0.27,0.13,(n=18)$ & Strom and Fredrickson (2008) \\
\hline $\begin{array}{l}\text { April-May, 2008, 2009, 2010-Non bloom, } \\
\text { Eastern Bering Sea, ice edge (cold years) }\end{array}$ & $-0.3(1.4)$ & $0.17(0.14), n=17$ & $0.08(0.12), n=17$ & Sherr et al. (2013) \\
\hline $\begin{array}{l}\text { April-May, 2008, 2009, 2010-Bloom, Eastern } \\
\text { Bering Sea, ice edge (cold years) }\end{array}$ & $0.8(1.7)$ & $0.21(0.12), n=21$ & 0.09 (0.08), $n=21$ & Sherr et al. (2013) \\
\hline $\begin{array}{l}\text { June-July, 2008, 2009, 2010-Eastern Bering } \\
\text { Sea (cold years; low stratification index in } \\
2008 \text {, stratification classification for } 2009 \text { \& } \\
2010 \text { not yet available) }\end{array}$ & $2.3-7.9$ & $-0.8-0.8,0.26,(n=61)$ & $0.0-0.9,0.26,(n=61)$ & This study \\
\hline
\end{tabular}
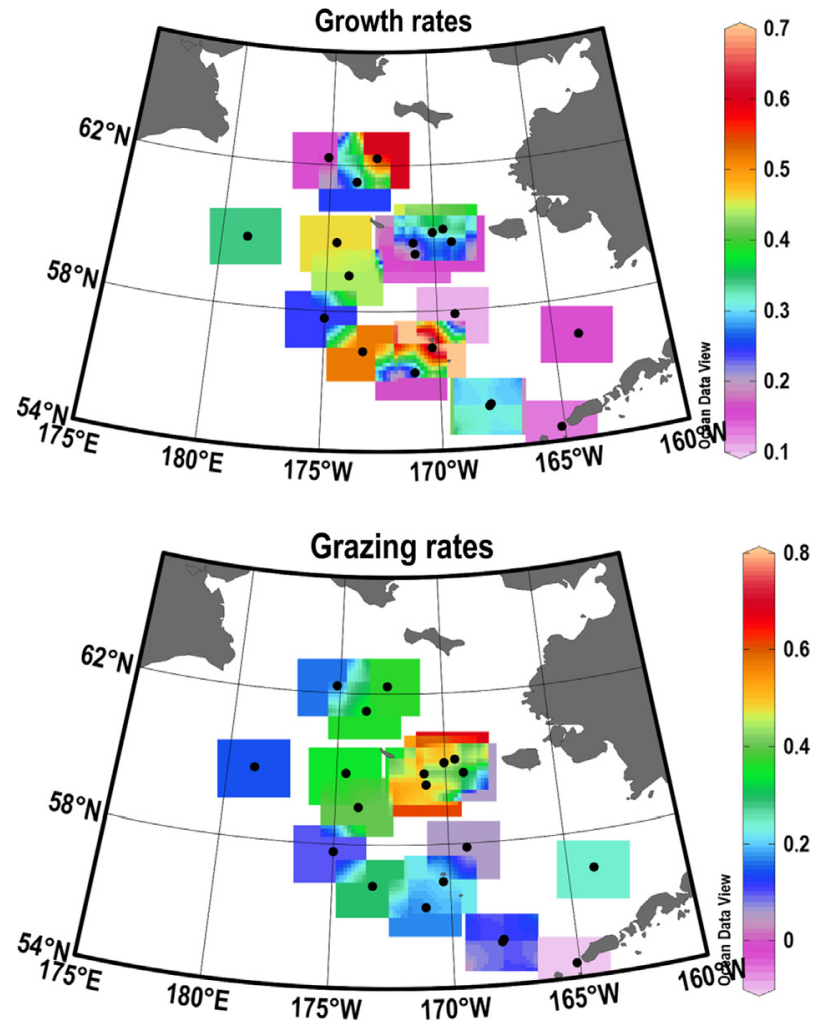

Fig. 7. Spatial distribution of phytoplankton growth $\left(\mu, \mathrm{d}^{-1}\right)$ (upper panel) and microzooplankton grazing $\left(\mathrm{g}, \mathrm{d}^{-1}\right)$ (lower panel) in the eastern Bering Sea, summer 2008.

growth and microzooplankton grazing were observed on the Middle Shelf near $60^{\circ} \mathrm{N}$, at the border between the St. Matthews and north Inner Shelf regions. This area was characterized by relatively low surface chlorophyll $a$ and moderate variable fluorescence. Diatom patches were observed to the east and haptophytes to the west of $170^{\circ} \mathrm{W}$ in this area. Phytoplankton growth and microzooplankton grazing were also relatively high on parts of the north Outer Shelf and Off Shelf north regions on the inner edge of the greenbelt. The greenbelt was characterized by low to moderate surface chlorophyll $a$, moderate variable fluorescence and dominance of phytoplankton biomass by cryptophytes and haptophytes. The Pribilof Island area was a hot spot for phytoplankton growth, with patches of both diatoms and haptophytes present, but microzooplankton grazing was moderate in this region. In contrast, the southeastern shelf and Peninsula area tended to have lower phytoplankton growth and microzooplankton grazing coefficients, although small flagellates, including cryptophytes and haptophytes, dominated (Goes et al., this issue).

In 2004, weak trophic coupling of phytoplankton growth to microzooplankton grazing was observed (Strom and Fredrickson, 2008), but strong coupling was observed in 1999 (Olson and Strom, 2002) and in summers of 2008, 2009, and 2010 (Table 6). On the shelf, microzooplankton grazing coefficients $(g)$ often exceeded phytoplankton growth coefficients $(\mu)$ in the mixed layer, but $g / \mu$ was $<1$ in Alaska Peninsula, Off Shelf and Outer Shelf waters in summer (Table 3). On average, grazing is equivalent to phytoplankton growth in the sea (Banse, 1992), with ratios of $g$ to $\mu$ exceeding 1 often found during the demise of blooms. For example, in the more southerly Gulf of Alaska, the ratio of microzooplankton grazing to phytoplankton growth on the Middle and Inner Shelf reaches a maximum in summer with $\mathrm{g} / \mu>1.0$ whereas in summer the ratio is lower on the Outer Shelf (Strom et al., 2007), similar to our observations in the Eastern Bering Sea. Another example is the Sea of Okhotsk, Liu et al. (2009) found that microzooplankton grazing $(g)$ was about three times higher than phytoplankton growth $(\mu)$ in late summer in nutrient-depleted shelf waters whereas in the higher nutrient shelf break and strait waters, $g / \mu$ estimates were $<0.5$. Ratios of microzooplankton grazing to phytoplankton growth in excess of 1 may be a general, although transient, feature of highly stratified boreal and Arctic Shelf ecosystems in summer.

Large copepods, such as Neocalanus spp., Calanus glacialis, and Metridia longa, have a strong prey preference for microzooplankton, but are largely absent from the Middle and Inner Shelf waters in summer (Vidal and Smith, 1986; Gifford, 1993; Campbell et al., 2009; Hunt et al., 2008). A reduction in top down control of microzooplankton on the Eastern Bering Sea Shelf may be partially responsible for the high biomass of microzooplankton (Stoecker et al., this issue) and their high grazing impact on the Bering Sea Shelf in summer. A similar phenomenon occurs on the Gulf of Alaska Shelf, where summer populations of large copepods are low and large cell-size microzooplankton are very abundant due to diminished top down control (Strom et al., 2007).

Although the grazing impact of microzooplankton on phytoplankton growth $(g / \mu)$ was highest in Middle and Inner Shelf waters, estimated microzooplankton ingestion of phytoplankton carbon and secondary production of microzooplankton was highest in the Alaska Peninsula, Off Shelf and Outer Shelf waters. This was due to higher chlorophyll levels than on the Middle and Inner 
Shelf. However, microzooplankton (20-200 $\mu \mathrm{m})$ biomass in the Off Shelf and Outer Shelf regions was about half that in the inner and middle domains (Stoecker et al., this issue). One reason for this discrepancy may be that grazing by nanozooplankton (which are not included in the microzooplankton biomass estimates) makes a larger contribution to grazing in the higher chlorophyll regions. Nanozooplankton have been shown to be more abundant in frontal areas on the Outer Shelf and at the shelf break than in lower chlorophyll inner and middle domains in summer (Flint et al., 2002). The relatively low biomass of $20-200 \mu \mathrm{m}$ microzooplankton (ciliates and large dinoflagellates) and high biomass of nanozooplankton in Peninsula, Off Shelf and Outer Shelf waters suggests a trophic cascade in which top down control of large microzooplankton by crustacean zooplankton releases nanozooplankton from grazing control. Conversely, large microzooplankton are probably relatively more abundant on the shelf in summer due to relaxation in top down control by large copepods which are mostly absent from the shelf in summer (Vidal and Smith, 1986; Hunt et al., 2008).

During the summer, the DCM in the northern domain can be well developed with $>10 \mu \mathrm{g}$ chlorophyll $a \mathrm{l}^{-1}$ at some stations (Lomas et al., 2012; Goes et al., this issue). Thus, the processes within the DCM may be very important to carbon flux and trophic transfer. Microzooplankton biomass (Stoecker et al., this issue) was usually similar in the DCM to that in the mixed layer above. Although grazing coefficients were also roughly similar in the mixed layer and corresponding DCM, the calculated ingestion rates in the DCM were higher than in the mixed layer (Fig. 5). This difference might be partly due to differences in $\mathrm{C}: \mathrm{Chl} a$ ratio in the mixed layer and in the DCM. The DCM samples ranged in depth from 26 to $35 \mathrm{~m}$ (Table 4), which was near or below the average depth of the 1\% PAR isolume, $30 \mathrm{~m}$ (Lomas et al., 2012). Microalgae grown at low irradiances have lower $\mathrm{C}$ :Chl $a$ than microalgae grown at higher irradiances; C:Chl $a$ of $\sim 25$ is often observed in light limited phytoplankton (Geider 1987). Applying an average C: Chl. of 50 for the Bering Sea (Lomas et al., 2012) to the DCM might result in over-estimation of microzooplankton carbon ingestion by up to $\sim 2$ fold. If we assume that phytoplankton growth was low at these depths due to the low irradiance, the ratio of grazing to phytoplankton growth must have been very high. Microzooplankton grazing is often important in erosion of "plankton patches" (Menden-Deurer and Fredrickson, 2010).

If we assume that microzooplankton growth efficiency was similar in the mixed layer and DCM, the DCM may be an important site of microzooplankton production during summer, particularly on the northern shelf. The lack of accumulation of microzooplankton biomass in the DCM suggests that predation pressure on microzooplankton is high and thus that these layers may be important in trophic transfer to higher trophic levels. The impact of microzooplankton grazing on phytoplankton and export fluxes can be under-estimated if grazing near the base of the euphotic zone is not included (Landry et al., 2011).

The decrease in variable fluorescence during the incubations from some stations suggests that dilution had a negative impact on phytoplankton photosynthetic physiology and hence potentially growth rate. This effect was most evident at Off Shelf and Outer Shelf "bloom" locations. This effect was not simply due to $\mathrm{N}$ limitation alone in the diluted treatments; it occurred in control and, in most cases, the paired nitrate amended dilutions. One of the assumptions of the dilution method is that dilution does not change the growth rate of phytoplankton, and this assumption likely was violated in at least some dilution experiments. A decrease in phytoplankton growth rate with dilution would result in an underestimation of the grazing coefficients. This may partially account for the low or non- significant grazing coefficients. Low grazing rates of microzooplankton for the biomass of microzooplankton have previously been reported in the SE Bering Sea during intense summer stratification and nutrient limitation of phytoplankton (Strom and Fredrickson, 2008). Non-significant microzooplankton grazing coefficients have also been reported during the spring at both non-bloom and diatom bloom ice edge stations (Sherr et al., 2013). In addition to non-significant grazing coefficients, statistically significant negative rates occur. Negative dilution grazing results are usually not reported (Dolan and McKeon, 2005), or the negative coefficients treated as "0" (Strom and Fredrickson, 2008). Negative rates can only occur when the growth rate of phytoplankton, $\mu$, is lower in the diluted treatment than in the whole seawater. In polar and subpolar ecosystems, non-significant and negative results in dilution experiments are common, particularly during Phaeocystis blooms (Calbet et al., 2011; Caron et al., 2000).

In culturing phytoplankton, a "lag" phase typically occurs after transfer of cells to new media, this has been ascribed to the time it takes cells to "ramp up" to better growth conditions, the "shock" of transfer and to lack of "conditioning factors" in the media. Perhaps something similar happens when phytoplankton are diluted with filtered seawater. Another possibility is that the mechanical stress involved in passage through filters results in release of "toxic" or "inhibitory" compounds into the filtered seawater used to make the dilutions. Strom and Fredrickson (2008) noted that release of diatom extracts from filters used to prepare filtered seawater may have inhibited growth of phytoplankton. During certain growth phases, $P$. pouchetti and many bloom forming diatoms produce cytotoxic aldehydes that are inhibitory to phytoplankton growth, including their own (Hansen and Eilertson, 2007; Paul et al., 2009). Mechanical stress can trigger the release of these compounds from cells (Hansen and Eilertson, 2007). We hypothesize that decreases in variable fluorescence and low or negative phytoplankton growth rates in diluted treatments could be due to presence of toxic aldehydes released from phytoplankton during preparation of filtered seawater. Preliminary results indicate that with some diatom and Phaeocystis blooms, treatment of filtered seawater with activated carbon to remove organic material prior to its use in dilution can reverse the negative effects on both " $\mu$ " and "g" (Stoecker and Nejstgaard, unpubl. data). However, contrary to expectation, grazing coefficients were not negatively correlated with abundance of $P$. pouchetti cells in the Bering Sea. Production of inhibitory compounds by Phaeocystis varies with life form and bloom stage (Nejstgaard et al., 2007), thus not all Phaeocystis cells will have the same impact on water chemistry. Furthermore, diatoms are also a source of cytotoxic aldehydes and are bloom dominants in the Bering Sea (Flint et al., 2002; Lomas et al., 2012). A simple relationship between one of these factors (Phaeocystis cells) and apparent low grazing coefficients is unlikely due to confounding factors.

Overestimation of microzooplankton grazing by the dilution technique may occur due to increases in microzooplankton populations because of the exclusion of mesozooplankton predators from the incubation bottles and starvation of microzooplankton in the diluted treatments (Dolan et al., 2000; Dolan and McKeon, 2005; Modigh and Franze, 2009). However, internal predation (microzooplankton predation on micro- and nanozooplankton) in incubations can lead to trophic cascades as well, decreasing grazing on phytoplankton (Stoecker and Evans, 1985; First et al., 2007, 2009). First et al. (2007) conducted dilution experiments in a range of temperate environments (coastal lagoons to offshore locations) and found that although microzooplankton biomass increased or decreased over time in most dilution experiments, adjusting for the actual grazer gradient did not significantly affect the estimated rates of microzooplankton grazing. In cold, subarctic waters the potential daily growth rate of microzooplankton is lower than in temperate waters and thus it is reasonable to 
assume that changes in grazer density and the effect on grazing coefficients would also be lower than in the First et al. (2007) study in temperate waters.

To evaluate the potential increase of microzooplankton geometric mean biomass in our incubations, the increased microzooplankton biomass $\left(C_{\mathrm{t}}\right)$ at the end of incubations was calculated as the average microzooplankton biomass $\left(C_{0}\right)$ for a domain (Stoecker et al., this issue) plus the estimated daily microzooplankton secondary production in that domain (Section 3.3). The geometric mean microzooplankton biomass, $\langle C\rangle$, during incubations was calculated as $\langle C\rangle=\left(C_{\mathrm{t}}-C_{\mathrm{o}}\right) /\left(\ln C_{\mathrm{t}}-\ln C_{\mathrm{o}}\right.$ ) (modified from Heinbokel (1978)). The average percent increase in microzooplankton biomass during an incubation was calculated as $(\langle\langle C\rangle-$ $\left.\left.\left.C_{\mathrm{o}}\right) \times 100\right) / C_{\mathrm{o}}\right)$. Using comparable domain data for biomass and secondary production, the potential elevation in microzooplankton biomass during the incubations was $3 \%, 4 \%, 10 \%$ and $11 \%$ in mixed layer dilution experiments conducted in the Inner Shelf, Middle Shelf, Outer Shelf, and shelf break/Off Shelf domains, respectively. Given the variability in estimated grazing typically found in dilution experiments, it seems unlikely that these relatively small potential increases in microzooplankton biomass would significantly influence estimates of microzooplankton grazing. In our experiments, it seems more likely that average microzooplankton grazing was underestimated, particularly in the Off Shelf and Outer Shelf waters, due to decreased phytoplankton growth in the diluted treatment in some incubations.

Whether or not grazing is underestimated or slightly over estimated, it is clear that microzooplankton grazing consumes most of phytoplankton production and that secondary production by microzooplankton is important. Most phytoplankton production is by $<5 \mu \mathrm{m}$ phytoplankton and thus passes through the microzooplankton link before it is available to crustacean zooplankton in summer. On the northern shelf, the DCM may often be a site of enhanced trophic transfer. Microzooplankton can comprise $49 \%$ or more of the food available to larger zooplankton on the Bering Sea Shelf in summer (Stoecker et al., this issue).

\section{Acknowledgments}

The authors thank the captain and crew of the USCG Healy, R/V Knorr and R/V T.G. Thompson for their assistance during the cruises. We thank Michael Lomas for advice and use of his fluorometer, Dean Stockwell and Michael Lomas for chlorophyll data, Carol Feierabend for enumerating Phaeocystis cells, Helga Gomes for help with the variable fluorescence measurements and Kristin Blattner for excellent technical assistance in 2008 and 2009. We thank Peter Lavrentyev for his thoughtful comments that improved the manuscript. DKS and AW were supported by Bering Sea Integrated Ecosystem Research Program (BSIERP) Project no. 55. JIG was supported by funding from the NASA. This is BEST-BSIERP Bering Sea Project publication no. 115, NPRB Publication no. 447 and UMCES Contribution no. 4807.

\section{Reference}

Banse, K., 1992. Grazing, temporal changes in phytoplankton concentrations, and the microbial loop in the open sea. In: Falkowski, P.G., Woods, A.D. (Eds.), Primary Productivity and Biogeochemical Cycles in the Sea. Plenum Press, New York, pp. 409-440.

Calbet, A., Saiz, E., 2005. The ciliate-copepod link in marine ecosystems. Aquat. Microb. Ecol. 38, 157-167.

Calbet, A., Saiz, E., Almeda, R., Movilla, J.I., Alcarez, M., 2011. Low microzooplankton grazing rates in the Arctic Ocean during a Phaeocystis pouchetti bloom (Summer 2007): fact or artifact of the dilution technique? J. Plankton Res. 33, 687-701.

Campbell, R.G., Sherr, E.B., Ashjian, C.J., Plourde, S., Sherr, B.F., Hill, V., Stockwell, D.A. 2009. Mesozooplankton prey preferences and grazing impact in the Western Arctic Ocean. Deep-Sea Res. II 56, 1274-1289.
Caron, D.A., Dennett, M.R., Lonsdale, D.J., et al., 2000. Microzooplankton herbivory in the Ross Sea, Antarctica. Deep-Sea Res. II 47, 3249-3272.

Chekalyuk, A., Hafez, M.A., 2008. Advanced laser fluorometry of natural aquatic environments. Limnol. Oceanogr., Methods 6, 591-609.

Dolan, J.R., McKeon, K., 2005. The reliability of grazing rate estimates from dilution experiments: have we over-estimated rates of organic carbon consumption by microzooplankton? Ocean Sci. 1, 1-7.

Dolan, J.R., Gallegos, C.L., Moigis, A., 2000. Dilution effects on microzooplankton in dilution grazing experiments. Mar. Ecol. Prog. Ser. 2000, 127-139.

First, M.R., Lavrentyev, P.J., Jochem, F.J., 2007. Patterns of microzooplankton growth in dilution experiments across a trophic gradient: Implications for herbivory studies. Mar. Biol. 151, 1929-1940.

First, M.R., Miller Jr., H.L., Lavrentyev, P.J., Pinckney, J.L., Burd, A.B., 2009. Effects of microzooplankton growth and trophic interactions on herbivory in coastal and offshore environments. Aquat. Microb. Ecol. 54, 255-267.

Flint, M.V., Sukhanova, I.N., Kopylov, A.I., Poyarkov, S.G., Whitledge, T.E., 2002. Plankton distribution associated with the frontal zones in the vicinity of the Pribilof Islands. Deep-Sea Res. II 49, 6069-6093.

Geider, R.J., 1987. Light and temperature dependence of the carbon to chlorophyll $a$ ratio in microalgae and cyanobacteria: implications for physiology and growth of phytoplankton. New Phytol. 106, 1-34.

Gifford, D.J., 1988. Impact of grazing by microzooplankton in the northwest arm of Halifax Harbor, Nova Scotia. Mar. Ecol. Prog. Ser. 47, 249-258.

Gifford, D.J., 1993. Protozoa in the diets of Neocalanus spp. in the oceanic subarctic Pacific Ocean. Prog. Oceanogr. 32, 223-237.

Goes, J.I., Gomes, H., do, R., Haugen, E., McKee, K., D'Sa, E., Chekalyuk, A.M., Stoecker D., Stabeno, P., Saitoh, S., Sambrotto, R., 2013. Fluorescence, pigment and microscopic characterization of Bering sea phytoplankton community structure and photosynthetic competency in the presence of a Cold Pool during summer. Deep Sea Res. II. (this issue [doi: 10.1016/j.dsr2.xxxx.xx.xxx]).

Hansen, E., Eilertson, H.C., 2007. Do the polyunsaturated aldehydes produced by Phaeocystis pouchetti (Hariot) Langerheim influence diatom growth during the spring bloom in Northern Norway? J. Plankton Res. 29, 87-96.

Heinbokel, J.F., 1978. Studies on the functional role of tintinnids in the southern California Bight. I. Grazing and growth rates in laboratory cultures. Mar. Biol. 47, 177-189.

Hunt Jr., G.L., Stabeno, P., Strom, S., Napp, J.M., 2008. Patterns of spatial and temporal variation in the marine ecosystem of the southeastern Bering sea, with special reference to the Pribilof Domain. Deep-Sea Res. II 55, 1919-1944.

Ladd, C., Stabeno, P.J., 2012. Stratification on the Eastern Bering Sea shelf revisited. Deep-Sea Res. II 65-70, 72-83.

Landry, M.L., 1993. Estimating rates of growth and grazing mortality of phytoplankton by the dilution method. In: Kemp, P.F., et al. (Eds.), Handbook of Methods in Aquatic Microbial Ecology. Lewis Publishers, Boca Raton, pp. 715-722.

Landry, M.R., Brown, S.L, Yoshimi, M.R., Selph, K.E., Bidigare, R.R., Yang, E.J., Simmons, M.P., 2008. Depth-stratified phytoplankton dynamics in Cyclone Opal, a subtropical mesoscale eddy. Deep-Sea Res. II 55, 1348-1359.

Landry, M.L., Calbet, A., 2004. Microzooplankton production in the oceans. ICES J. Mar. Sci. 61, 501-507.

Landry, M.L., Calbet, A., 2005. Reality checks on microbial food web interactions in dilution experiments: responses to the comments of Dolan and McKeon. Ocean Sci. 1, 39-44.

Landry, M.R., Selph, K.E., Yang, E.J., 2011. Decoupled phytoplankton growth and microzooplankton grazing in the deep euphotic zone of the eastern equatorial Pacific. Mar. Ecol. Prog. Ser. 421, 13-24.

Levinsen, H., Nielsen, T.G., 2002. The trophic role of marine pelagic ciliates and heterotrophic dinoflagellates in Arctic and temperate coastal ecosystems: a cross-latitude comparison. Limnol. Oceanogr. 47, 427-439.

Liu, H., Suzuki, K., Nishioka, J., Sohrin, R., Nakatsuka, T.,2009. Phytoplankton growth and microzooplankton grazing in the Sea of Okhotsk during late summer of 2006. Deep-Sea Res. I 56, 561-570.

Liu, H., Suzuki, K., Saino, T., 2002. Phytoplankton growth and microzooplankton grazing in the subarctic Pacific Ocean and the Bering Sea during summer 1999. Deep-Sea Res. I 49, 363-375.

Lomas, M.W., Moran, S.B., Casey, J.R., Bell, D.W., Tiahlo, M., Whitefield, J., Kelly, R.P., Mathis, J.T., Cokelet, E.D., 2012. Spatial and seasonal variability of primary production on the Eastern Bering Sea shelf. Deep-Sea Res. II 65-70, 126-140.

Menden-Deurer, S., Fredrickson, K., 2010. Structure-dependent, protistan grazing and its implication for the formation, maintenance and decline of plankton patches. Mar. Ecol. Prog. Ser. 420, 57-71.

Merico, A., Tyrrell, T., Lessard, E.J., Oguz, T., Stabeno, P.J., Zeeman, S.I., Whitledge, T.E., 2004. Modelling phytoplankton succession on the Bering Sea shelf: role of climate influences and trophic intractions in generating Emiliamia huxleyi blooms 1997-2000. Deep-Sea Res. I 51, 1803-1826.

Modigh, M., Franze, G., 2009. Changes in phytoplankton and microzooplankton populations during grazing experiments at a Mediterranean coastal site. J. Plankton Res. 31, 853-864.

Moran, S.B., Lomas, M.W., Kelly, R.P., Gradinger, R., Iken, K., Mathis, J.T., 2012. Seasonal succession of net primary productivity, particulate organic carbon export and autotrophic community composition in the eastern Bering Sea. Deep-Sea Res. II 65-70, 84-97.

Nejstgaard, J.C., Tang, K.W., Steinke, M., Dutz, J., Koski, M., Antajan, E., Long, J.D., 2007. Zooplankton grazing on Phaeocystis: a quantitative review and future challenges. Biogeochemistry 83, 147-172. 
12

D.K. Stoecker et al. / Deep-Sea Research II

Olson, M.B., Strow, S.L., 2002. Phytoplankton growth, microzooplankton herbivory and community structure in the southeast Bering Sea: insight into the formation and temporal persistence of an Emiliania huxleyi bloom. Deep-Sea Res. II 49, 5969-5990.

Ortiz, Y., Wise, F., Grig, A., 2012. Marine regions boundary data for the Bering Sea shelf and slope. UCAR/NCAR-Earth Observing Laboratory/Computing, Data, and Software Facility. Dataset. doi:10.5065/D6DF6P6C.

Parsons, T., Maita, Y., Dali, C., 1984. A Manual of Chemical and Biological Methods for Seawater Analysis. Pergamon Press, New York.

Paul, C., Barofsky, A., Vidoudez, C., Pohnert, G., 2009. Diatom exudates influence metabolism and cell growth of co-cultured diatom species. Mar. Ecol. Prog. Ser. $389,61-70$

Rose, J.M., Carom, D.A., 2007. Does low temperature constrain the growth rates of heterotrophic protists? Evidence and implications for algal blooms in cold waters. Limnol. Oceanogr. 52, 886-895.

Rose, J.M., Fitzpatrick, E., Wang, A., Gest, R.J., Carom, D.A., 2013. Low temperature constrains growth rates but not short-term ingestion rates of Antarctic ciliates. Polar Biol. 36, 645-659.

Sambrotto, R.N., Mordy, C., Zeeman, S.I., Stabeno, P.J., Macklin, S.A., 2008. Physical forcing and nutrient conditions associated with patterns of ChI a and phytoplankton productivity in the southeastern Bering Sea during summer. Deep-Sea Res. II 55, 1745-1760.

Cher, E.B., Sherr, B.F., Hertz, A.J., 2009. Microzooplankton grazing impact in the western Arctic Ocean. Deep-Sea Res. II 56, 1264-1273.

Sheri, E.B., Sherr, B.F., Ross, C., 2013. Microzooplankton grazing impact in the Bering Sea during spring sea ice conditions. Deep-Sea Res II 94, 57-67.

Stabeno, P.J., Farley Jr., E.V., Rachel, N.B., Moore, S., Moody, C.W., Map, J.M., Overland, J.E., Pinchuk, A.I., Sigher, M.F., 2012a. A comparison of the physics of the northern and southern shelves of the eastern Bering Sea and some implications for the ecosystem. Deep-Sea Res. II 65-70, 14-30.
Stabeno, P.J., Kachel, N.B., Moore, S.E., Map, J.M., Sigher, M., Yamaguchi, A., Zerbini, A.N., 2012b. Comparison of warm and cold years on the southeastern Bering Sea shelf and some implications for the ecosystem. Deep-Sea Res. II 6570, 31-45.

Stockwell, D.A., Whitledge, T.E., Zeeman, S.I., Coyle, K.O., Map, J.M., Brodeur, R.D., Pinchuk, A.I., Hunt, G.L., 2001. Anomalous conditions in the southeastern Bering Sea, 1997: nutrients, phytoplankton and zooplankton. Fish. Oceanogr. 10, 99-116.

Stoecker, D.K., Evans, G.T., 1985. Effects of protozoan herbivory and carnivory in a microplankton food web. Mar. Ecol. Prog. Ser. 25, 159-167.

Stoecker, D.K., Weigel, A., Stockwell, D., Lotas, M., 2013. Microzooplankton: Abundance, biomass and contribution to chlorophyll in the Eastern Bering Sea in summer. Deep-Sea Res. (this issue [oi: 10.1016/j.dsr2.xxxx.xx.xxx]).

Strow, S.L., Fredrickson, K.A., 2008. Intense stratification leads to phytoplankton nutrient limitation and reduced microzooplankton grazing in the southeastern Bering Sea. Deep-Sea Res. II 55, 1761-1774.

Strow, S.L., Mari, E.L., Olson, M.B., 2007. Microzooplankton grazing in the coastal Gulf of Alaska: variations in top-down control of phytoplankton. Limnol. Oceanogr. 52, 1480-1494.

Strow, S.L., Olson, M.B., Macri, E.L., Mordy, C.W., 2006. Cross-shelf gradients in phytoplankton community structure, nutrient utilization, and growth rate in the coastal Gulf of Alaska. Mar. Ecol. Prog. Ser. 328, 75-92.

Sukhanova, I.N., Seminar, H.J., Venttsel, M.V., 1999. Spatial and temporal variability of phytoplankton in the Bering Sea. In: Loughlin, T.R., Ohtani, K. (Eds.), Dynamics of the Bering Sea. University of Alaska Sea Grant, Fairbanks, pp. $453-483$.

Vidal, J., Smith, S., 1986. Biomass, growth, and development of populations of herbivorous zooplankton in the southeastern Bering Sea during spring. DeepSea Res. 33, 523-556.

Please cite this article as: Stoecker, D.K., et al., Microzooplankton grazing in the Eastern Bering Sea in summer. Deep-Sea Res. II (2013),

http://dx.doi.org/10.1016/j.dsr2.2013.09.017 